\title{
The Life and Activities of Professor Gottfried Albrecht Germann, the First Natural History Professor at the University of Tartu
}

\author{
Heldur Sander \\ Mahtra 9-121, \\ Tallinn 13811, Estonia \\ E-mail: heldsander@gmail.com
}

\begin{abstract}
The article analyses the life and work of Gottfried Albrecht Germann (1773-1809), the first professor of natural history in general and botany in particular at the University of Tartu after its reopening in 1802. He was born in Riga in 1773. After graduating from the local Cathedral School, he went on to the University of Jena. Next, he studied at the universities of Würzburg, Berlin and Kiel. At the latter institution, he also defended his doctoral dissertation. After return from Germany, Germann worked as a medical doctor with Count Jacob Johann Sievers, whose home manor was at Bauni, Livonia. While in Sievers' employ, he resided in St. Petersburg, Bauni and Valmiera, and accompanied the former on his trips. On 24 February 1802, Germann was selected to serve at the University of Tartu. His main occupation was teaching, but he also bore the burden of founding the Chair of Natural History and the Botanical Garden. At the University, Germann lectured general natural history and various narrower specialities for 12-16 hours per week. In addition, he took an active part in the life of the University and in the diverse activities of the professors. While at the University, Germann also undertook several trips. These covered the provinces of Estonia and Livonia and the Finnish part of Russia. Germann's research involved ornithology and botany. In addition, he compiled catalogues of botanical garden collections. He died young, yet was able to leave an altogether meritorious mark as a teacher of the University of Tartu with his work and activities.
\end{abstract}

Keywords: activity of university, Botanical Garden, botany, Count Sievers, Gottfried Albrecht Germann, Jena, lectures, Natural History Cabinet, ornithology, plant collections, professor of natural history, Riga, travels, University of Tartu 
The Life and Activities of Professor Gottfried Albrecht Germann, the First Natural History Professor at the University of Tartu

\section{Introduction}

The University of Tartu (Germ. Kaiserliche Universität zu Dorpat; Rus. Imperatorskii Derptskii Universitet) was reopened in Tartu on 21 and 22 April 1802 (Siilivask, 1982, pp. 36-37). In this connection, the university's board of trustees had to find lecturers who would hold a degree. The chosen professors were to be suitable local or foreign scholars who, beyond their professional knowledge, could be expected to have moral perfection. Pursuant to $\$ 26$ of the Imperial Plan, the latter characteristic was to be taken into particular consideration by the trustees. The relevant condition added by the trustees was to address persons who could be expected to accept the invitation (Luts, 2002, p. 16). Gottfried Albrecht Germann was elected professor of natural history and botany at the Faculty of Philosophy and Natural History, with an emphasis on botany (Der Prof. der Naturgeschichte überhaupt und der Botanik inbesondere). He was employed by the University of Tartu on February 24, 1802 (Storchs, 1804, p. 223; Ewers, 1827, p. xxvi; Krause, 1902, pp. 229-250, 235, 362).

The reopening of the University of Tartu coincided with the establishing of a botanical garden, which largely supported the conventions and traditions of European universities at the time (Kriisa, 2016a, pp. 10-45). However, since monastic and urban gardens emerged in the three Baltic provinces-Estonia, Livonia and Courland-already in the Middle Ages, the founding of the Botanical Garden of the University of Tartu did not fall to an empty space. The previous developments had already set the stage with well-functioning ornamental, medicinal and household gardening, knowledge of the local climate and plant-growing skills. Foreign gardeners with various skills arrived early to the Estonian, Livonian and Courland provinces and found employment here (Pūka, 2010, pp. 15-30). The thriving of ornamental gardening gained prominence in the 17th century; at the end of the century, David Krieg, who established relations with England, also began his first exploration of nature (Tering, 2015, pp. 39-83). He was the first known scholar to compile the catalogue of Livonian flora, his preliminary work is still preserved in St. Petersburg and probably in the British Library and Museum. Even from spring to autumn 1698, he went to America to collect plants, butterflies, insects, and other natural memorabilia.

The development of ornamental gardening in the area continued in the first quarter of the 18th century, more prominently with the establishment of Kadriorg Park in Tallinn. In the second half of this century, local nature exploration and the design of gardens and landscaping revitalised manors and pastorates. 
More nurseries were established, and ornamental and household gardening was developed to a high standard. In terms of richness of species (the number of cultivated species) and their design, the nurseries and gardens were not far behind the ornamental gardens in St. Petersburg, which were being founded in the new capital of the Russian Empire (Schmidt, 1800, pp. 2-25; Buek, 1804, pp. 2-14; Zigra 1805, pp. 1-41; Hein, 2007, pp. 17-87; 2010, pp. 5-38; 2016, pp. 10-23; Maiste, 2006, pp. 131-148; 2013, pp. 155-180; Sander, 2017, pp. 45-82). The gardens established in St. Petersburg, however, were largely a model, owing to the Baltic German elite working there. Also, we cannot forget the climate here, as in 1768-1987 alone (in the period of 219 years) there were 23 very cold winters compared to the annual average temperature (10.5\%), and also 52 very warm winters, constituting $23.7 \%$ (Tarand et al., 2013, p. 610). On the one hand, the harsh winters led to the destruction of gardens, but on the other hand, it again encouraged re-establishment, provided knowledge and skills.

Gottfried Albrecht Germann's life and activities and the establishment and vegetation ${ }^{1}$ of the University of Tartu Botanical Garden connected to him, have, to a lesser or greater extent, been the subject of several studies (Storch, 1804, pp. 236-237; Willkomm, 1873, pp. 1-179; Krause, 1902, pp. 87-89; Levitskiy, 1902, pp. 343-344; Lipshits, 1947, p. 263; Lievre, 2004, pp. 37-38; Kriisa 2016a, pp. 4-64; 2016b, pp. 153-188). This research, based on primary sources, is more or less related to our earlier work (Sander et al., 2009, pp. 46-50; Sander \& Meikar, 2009, pp. 72-85; 2011, pp. 230-256; Sander, 2010, pp. 90-93; 2018, pp. 1041-1054; Sander et al., 2014, pp. 53-110) but has been redesigned and updated. The article does not go into detail here about all of Germann's activities and involvement in the university, as some of them are separate topics and have also been addressed. This applies in particular to the landscaping of the Toome Hill in Tartu (Ormisson-Lahe, 2011, pp. 333-366). Neither does the article cover the construction of the Botanical Garden as a whole, as this aspect has already been thoroughly researched and the results published (Kriisa, 2016a, pp. 32-45, 72-78; 2016b, pp. 153-188).

Modern plant names in his work follow those given in the database The Plant List. A working list of all plant species (The Plant List, n.d.). 


\section{The birth and studies of Gottfried Albrecht Germann}

Gottfried Albrecht Germann (Fig. 1) $)^{2}$ was born on 8 December 1773 as the second child and oldest son of the vice-rector of the Riga Dome School (Subrektor der Domschule Riga). His parents Albrecht Germann (1744-1818) and Gertrud Dorothea Germann (née Erdmann; 1751-1831) had 18 children, 10 of whom survived into adulthood. Germann's family tree, with its extending branches, can be traced back to quite an ancient history, so it is not always clear how all the members are connected to the family of Albrecht Germann. Germann senior was born in the small town of Rastenberg in East Prussia (now in Gierłoż, Kętrzyn County, Poland), he studied at the University of Königsberg (now Kaliningrad) in 1763-1768 and accepted a teaching position at the Riga Dome School in 1768, where he was employed for fifty years (Seuberlich, 1924, pp. 111-118; Hollander, 1980, pp. 165, 176).

At that time the Riga Dome School had a class system, with each main teacher responsible for one class. The teachers who had already been working at the Dome School for a long time were Johann Georg Rievethal (since 1788), who as the "presiding teacher" was the school's director, Albrecht Germann (since

2 The notable German portraitist C. Ch. Vogel von Vogelstein painted Professor Germann in his Tartu home with his favourite pet, a turquoise-fronted amazon (Amazona aestiva Linnaeus, 1758), and several books on the desk in front of him. The artist has emphasised the professor's special interest in ornithology - the open book in his hand is the volume on birds of the German translation of Georges-Louis Leclerc's (Comte de Buffon, 1707-1788) L'Histoire naturelle, générale et particulière, the foremost encyclopaedia of natural sciences of the time, and the professor is looking at the bird on his forearm as if comparing it to the description in the book. (Kukk, 2017) 
1768), and Johann David Sandt (since 1779) (Hollander, 1980, p. 165). The Baltic historian Bernhard Albert von Hollander (1980, p. 176) wrote: "Albrecht Germann stood out among the teachers at the Dome School at the beginning of the [19th] century [...]; he must have been extraordinarily sensitive and had a heartfelt fondness of the youth. Shortly after the celebration of his fifty-year work anniversary, he went peacefully to his eternal rest (1818).”

Gottfried Albrecht Germann studied at the Riga Dome School from 1782 to 1792, and from 1792 to 1796 continued his studies at the Faculty of Medicine and Natural Sciences of the University of Jena. At Jena, his teachers and mentors were outstanding medical and natural scientists of their time: Justus Christian Loder (1753-1832), Christoph Wilhelm Hufeland (1762-1836), Johann Christian Stark senior (1753-1811), Christian Gottfried Gruner (1744-1815), and August Johann Georg Karl Batsch (1761-1802), in whose lectures Germann received a broad-based education in medicine and the natural sciences. Among other teachers of Gottfried Albrecht Germann was the philosopher Carl (Karl) Leonhard Reinhold (1757-1823, at Jena 1787-1794) (Recke \& Napiersky, 1829, pp. 25-26; Levitskiy, 1902, pp. 343-344; Seuberlich, 1924, pp. 113; Lipshits, 1947, pp. 263; Lenz, 1970, p. 238; Sander et al., 2009, pp. 46-50). Of the mentioned teachers, Loder was of Baltic-German origin, born in Riga and since 1778, professor of anatomy, surgery, and obstetrics at the University of Jena. He was talented, hard-working, and was able to follow through on his ambitions (Lenz, 1970, p. 465; Tering, 2008, pp. 236-238; Hellfritzsch, 2015, pp. 91-92). In 1793, Germann became a founding member of the Jena Naturalists' Society (Die Jenaer Naturforschenden Gesellschaft), which had been initiated by August Johann Georg Karl Batsch (1761-1802) and operated under his leadership. The society's constitution listed 16 topics for future activities, among these were carrying out meteorological observations and the analysis of the fruit-bearing quality of decorative plants, including disproving erroneous opinions regarding the artificial system of plants. In 1794, during Germann's studies at Jena, renovations of the botanical garden began, and August Johann Georg Karl Batsch became its first director. It is not known whether or to what extent Germann participated in the development of the botanical garden, perhaps indirectly by procuring seeds. Could it be possible that what he saw and experienced might later have influenced Germann's founding of the University of Tartu's botanical gardens?

There were 47 regular founding members (ordentliche Mitglieder) of the Jena Naturalists' Society, 5 of whom were Baltic Germans. Besides Germann, 
these were Peter Gottlieb Horn from Estonia, Friedrich Ludwig Lindner from Courland, and Ludwig Reinhold Stegmann from Livonia. The society's secretary was Alexander Nicolaus Scherer (1771/1772-1824), who was born in St. Petersburg and died there, whose mother was Baltic German. Scherer had been a student at the Riga Dome School. Later he became a professor at the University of Tartu (1803-1804), then returned to St. Petersburg and became a member of the Academy of Sciences (Batsch, 1793, pp. 43-48; Recke \& Napiersky, 1832, pp. 53-57; Stieda, 1890, pp. 43-48; Tering, 2008, pp. 375-378). Among the 25 corresponding members of the Jena Naturalists' Society were Aaron Christjan Lehrberg from Tartu, who was away at the time on a trip to England, and a Riga Dome School teacher Johan David Sandt, who had also been Germann's teacher. They were joined in 1794 by Gustav Ambrosius Wilhelm Bergmann from Livonia and Johan Philipp Hayne from Courland, who by then had returned home. Upon the foundation of the society, Germann became responsible for managing the collections. Evidence of the diversity of Germann's interests is his donation of an insect collection to the society, and the comparative study he undertook about the climate of Thuringia and Livonia (Ueber den Unterschied des Klimas von Livland und Thüringen, mit eingestreuten naturhistorischen Notizen). Germann gave a talk on the latter topic in 1793 at Jena, but the research itself has been lost. In 1793, he also spoke about the climate of Jena, adding remarks on natural history and comparing the ordinary weather conditions in Jena and Livonia (Recke \& Napiersky, 1829, p. 25; Tering, 2008, pp. 376-377).

Many of the Baltic Germans who had studied at Jena became Germann's friends; he mentioned three of them whom he had met during a research trip to the provinces of Estonia and Livonia in 1803; two of them were also interested in botany and had collected plants (Germann, 1805b, pp. 71-72; 75-76, 80; 100). The first, Georg Christian Sabler (1776-1819), was born in Haljala in northern Estonia, studied theology in Germany, matriculated in the University of Jena in 1794 , and was ordained as a pastor in 1798 . During the years $1798-1819$ he was a pastor of the Saint Mauritius congregation in Haljala. The second friend that Germann mentioned was Jacob Johann Anton Hirschhausen (1773-1837), who was born in Tallinn and matriculated in the University of Jena in 1791 (and was still pursuing his studies there in 1794). He was ordained in 1803 and served as pastor of the Jóelähtme congregation in Estonia in the years 1803-1809. Germann's third friend was Christoph Friedrich Mickwitz III (1773-1851), born in Koeru in 1773, studied at the Tallinn gymnasium 1782-1790 and later at the University of Jena 1790-1793 (in 1793, he was still in Jena, where he was studying philosophy, theology, and natural sciences). In 1797-1838, Mickwitz 
was the pastor of the Elizabeth Church in Lihula and the St. Nicholas church in Kirbla (Aarma, 2007, pp. 118, 187, 228; Tering, 2008, p. 456).

In 1795, Germann went to the University of Würzburg, where he studied with Professor Carl Caspar von Sieboldi (1736-1807) and practised at the large hospital there. In 1796, he worked for four weeks at the University of Berlin in the natural history cabinet of the physician and natural scientist Marcus Elieser Bloch (1723-1799), compiler of a 12-volume encyclopaedic study of fish. During this time, Germann drew up a complete catalogue of the collections held there. Germann then went on to audit the botany lectures of Georg Heinrich Weber (1752-1828) at the University of Kiel, and it was here that his interest in botany originated. At Kiel, in 1796, Germann defended his doctoral degree in medicine with a dissertation entitled De influxu aëris frigidi et calidi in morbus et sanitatem hominum - pro gradu doctoris Medicinae et Chrurgiae. Kiliae Holsatorum, 1796. (Recke \& Napiersky 1829, pp. 25-26; Trautvetter, 1880, pp. 91-92; Brennsohn, 1905, p. 171; Lipshits, 1947, p. 263; Lenz, 1970, p. 238; Sander et al., 2009, pp. 542-546; Tering, 2010, p. 385). Germann's journey to the University of Kiel has been connected to the appointment of Carl Leonhard Reinhold as ordinary professor in 1794 (Tering, 2019).

Germann's doctoral dissertation is written in Latin and German in the field of medical geography; his inquiry discusses the climatic causes of illnesses. $\mathrm{He}$ presents examples from Egypt, the Philippines, and North America. He cites the natural scientist Kurt Sprengel's (1795, pp. 502, 506) handbook of pathology and the first parts of Lionel Chalmer's $(1788$, p. 22) monograph on North America. Germann was impressed by the medical-geographical monograph by Leonhard Ludwig Finke, and cited its first and second parts at length (Finke, 1792: Erster Band, p. 226; Zweyter Band, pp. 116, 117). It seems apparent that he did not have access to, or did not need the third part of the same work, which contains an overview of Russia and also pays significant attention to the provinces of Courland, Livonia and Estonia, including Tallinn (Finke, 1795, pp. 655-674).

Based on the above, it is difficult to estimate the extent to which Germann began developing his later scientific interests in botany during his years at Kiel. However, his 1803 expedition to the provinces of Estonia and Northern Livonia indicates that he already had a strong interest in botany in Germany. For example, in 1803, he writes about Carlina acaulis L. and C. vulgaris L., which he had found in Northern Estonia. "Surely you can imagine how happy I was to find my old German acquaintance here unexpectedly. [....] How common Carlina vulgaris had seemed to me in various places in Germany, and how pleasant a find 
it was for me here!" He adds, "I have searched in vain for Carlina acaulis in my homeland; I had become acquainted with it near Jena; it is also reported to grow in Southern Livonia." Later on, he makes a note regarding the plant: "In a small sandy pine grove halfway to Paldiski I again chanced upon an old acquaintance; though it is common in Germany, here it is a very rare, beautiful plant, Armeria maritima (Mill.) Willd." (Germann, 1805b, pp. 67-68; 83).

\section{Return to Russia and the years prior to coming to the University of Tartu}

Having returned to Russia from Germany, Germann took the medical doctor's examination in 1797 in St. Petersburg (Seuberlich, 1924, p. 113). Since in Russia a doctorate from a foreign university did not automatically confer the right to practice medicine, one had to pass a supplementary exam at the St. Petersburg Medical Collegium and apply for a licence to practice medicine throughout the Russian Empire (Tering, 2008, p. 370). We do not know at what time Germann became acquainted with the Rakvere-born general, diplomat and government official Count Jacob Johann Sievers (1731-1808), who was the district magistrate for Livonia (1783-1786 and 1797-1802). Count Sievers was a senator from 1796 onward, and from 1797 to 1800 he was in civil service as the chief director of a water management institution (Hauptdirector d. Wasserkommunikation). He was quite wealthy and at one time the owner of many estates: in Estonia he owned Haimre (Heimar), Raasiku (Rasik) and its auxiliary estate Kambi (Kampen), in Livonia since 1747, the owner of his home estate Baun,i (Bauenhof), Milite (Neuhall), Vikịi (Zarnau) and Koškele (Ostrominsky), four estates in Ingria, two in the province of Polotski and, in addition, Sackala in Finland. In the years 1798-1808 he was the patron of the St. Peter Church in St. Petersburg (Lenz, 1970, p. 732).

How Germann and Count Sievers met and their more detailed connections must remain unclarified at this point, as it would require time-consuming research, primarily in the archives in Riga, but also in St. Petersburg. Materials on Germann can be found particularly in Riga, in the personal archives of Count Sievers, or the Bauni estate. At any rate, upon Germann's return from Germany, he was assigned to the post of district physician in the parish of Matī̌su (St. Matthäi) at Count Sievers' Bauni estate, where he worked in 1797-1798; in 1798-1800 he was Sievers' house physician in St. Petersburg (Recke \& Napiersky, 1829, p. 25; Lenz, 1970, p. 238; Sander et al., 2009, p. 542). Germann also accompanied 
Count Sievers on his travels as his personal physician (Rambach, 1809, p. 75), and thus it seems that they were closely acquainted.

Working as the Bauni district physician and Count Sievers' personal physician was significant in many ways in Germann's life. Count Sievers was a prominent person at the court of Catherine II of Russia, and was related to many well-known people; his home estate was one of Livonia's most impressive ones, important both culturally and in terms of its gardens (Baltinšs, 2006, pp. 107-136; Tamul, 2007, pp. 105-108). It is likely that at Bauni Germann began to take interest in cultured plants, and the garden plants he saw and learned about became useful later when he worked at the University of Tartu. The following has been written about Count Sievers:

Every person who is used to living according to a strict plan creates a new world around himself whenever the situation changes. This was also true of Sievers at his country residence [Bauni]. A new building was erected in the style of an English country manor, surrounded by a park where he grew numerous foreign species of trees and where, without worrying about the cost, he would mail-order seeds from Germany. (Rambach, 1809, pp. 51-52)

The manor park had a great diversity of plants and was well designed. Among the trees growing there were black walnut (Juglans nigra L.) (Amerikanischer nussbaum), an abundance of Larix sp. (then Pinus larix L.) and a large number of Weymouth pine (Pinus strobus L.) (Germann, 1807a, pp. 76, 103) Especially valuable and one of Count Sievers' favourites was the Juglans nigra L. from North America, which is rare here even nowadays (Germann, 1807a, p. 76; Rambach, 1809, p. 52; Blum, 1858, p. 101). We learn from Germann (1807a, p. 76) that trees of this species manage quite well here. At the Bauni Manor there were many black walnut trees, the fruit of which was gathered: when planted these sprouted very well. The full-grown trees had already borne fruit a second time. It is likely that the black walnut tree of University of Tartu botanical gardens originated from Bauni. After Count Sievers' death, it was stated): "We owe him thanks that larches and the black walnut tree adorn Livonia. He decreed that every year each farmer was to plant a set number of fruit trees from Sievers' nursery, and that decree remains in effect today." (Rambach, 1809, p. 52) Thus we can see that there was a nursery at Bauni, as was also true of many other manors.

Count Sievers' interests were broad. His friend, Pastor Gustav Bergmann (17491814) made the following remark in a letter to his son Benjamin, who was in Leipzig: 
I found the gentleman privy councillor at his manor occupied with spinning silk from silkworms; I acquired a few mulberry trees from him and would like to establish a small silk farm myself. I do not consider such an activity undignified for a philosopher. Although he only had silk for two pairs of stockings, my respect for the privy councillor turned into admiration. (Bergmann, 1896, p. 199)

Several thousand larches were grown at Bauni, and more would be planted every year; a large number of seeds were dispersed (Germann, 1807a, p. 103). In the forest culture there was most probably more West Russian larches (Larix archangelica C.Lawson 1836) (Kozhin \& Sennikov, 2016, pp. 79-80), as has been accepted and genetically proven by Russia's botanists; internationally, this species is generally regarded as Siberian larch (L. sibirica Ledeb. 1833 sensu lato), of which the previously mentioned species name is a synonym (Farjon et al., 2019).

In his agricultural and gardening pursuits, Count Sievers gladly took advice from Pastor Gustav Bergmann. Thus, in a 1791 letter to his oldest daughter Katharina, who had married Karl Johann von Günzel (Lenz, 1970, p. 276) and was living in Vyborg, he remembers the larch avenue that Bergmann had planted for him (Bergmann, 1896, p. 199). Bergmann had studied at the University of Leipzig from 1767 to 1770 and worked as a pastor in Äraiši (Arrasch) in 1771-1780, Mazsalaca (Salisburg) in 1781-1785 and Rūjiena (Rujen) in 1785-1814 (Lenz, 1970, p. 56). He has also written extensively about the Bauñi manor (Baltiňš, 2006, pp. 117-124).

At Bauni, the white pines and larches (mostly $L$. decidua Mill) from Count Sievers' time are still standing, as we found out on a research trip in 2009. Of the six white pines measured, the three thickest ones had a breast height perimeter $(\mathrm{PBH})$ of 295, 253, and $197 \mathrm{~cm}$. Along the preserved larch avenue that runs in a southwest-northeast direction, there were 86 trees, 45 of them in the northwest and 41 in the southeast row. The three thickest larches had PBH values of 445, 424, and $408 \mathrm{~cm}$, and they stood in the northwest row. (Sander, 2009, pp. 60-62) Dendrochronological investigations with a new growth drill at the height of $1.3 \mathrm{~m}$ of an old white pine showed 199 annual rings, spanning the years 1810-2008. However, the new growth drill did not penetrate to the heart of the tree, and thus it is somewhat older. Of the 13 larches the ages of 3 trees at the height of $1.3 \mathrm{~m}$ were 207, 204, and 201 years. Here also the drill may not always have hit the medulla of the tree (Läänelaid, 2019). Thus, it is highly likely that the white pines and larches planted in Count Sievers' lifetime and probably also the larches that Bergmann planted in the 1780s are still alive. 
During the first years of the University of Tartu, Julie Germann relates to Johann Karl Simon Morgenstern:

Today I received another package of larch and white pine seeds from my grandfather. He writes that according to his instructions I am to share them with you. Please take half of each kind; I am adding the directions sheet. The seeds should be soaked for two hours in cold water and then sowed in soil mixed generously with sand. The gardener must choose a shady location so that the sun's rays will not hinder the sprouting of these northern trees. (Germann, J., 1803)

Most likely, Morgenstern planted these seeds in his personal garden on Toome Hill. When the University of Tartu distributed plots of land that it owned on Toome Hill to citizens of Tartu, Morgenstern applied for one on 1 June 1803. He was allotted a plot on 21 October 1803 across from the residence of Baron Johann Friedrich Emanuel von Ungern-Sternberg, vice-curator of the University. From that point on, Morgenstern turned the plot into a fenced-in garden, at great expense; a residence was never built there. For the garden, Morgenstern obtained plants from several places, including the Riga gardening company of Johann Hermann Zigra (1805, pp. 1-41), whose greenhouses and outdoor gardens contained 1,696 plant designations. When Morgenstern donated the garden to the University of Tartu in 1848, various native and foreign trees were abundantly growing there. These included Tartu's only Populus nigra 'Italica' (Italienische Pyramidalpappel) (EAA, 1848-1903, EAA.402.5.409, pp. 3-4), which was of remarkable height, possibly originating from Zigra's nursery. It stood amidst the twelve species and cultivars of poplars (Zigra, 1805, p. 39).

Gottfried Albrecht Germann also personally distributed the seeds of Bauni larches and placed the following advertisement in the Tartu newspaper:

I have [...] obtained a notable amount of Lerchenbaum seeds from Count Sievers; these are being gathered at his manor with instructions to distribute them free of charge to anyone who is interested in planting trees. Therefore I invite manor owners and owners of large gardens to come and visit me, and I will give them one portion of a quarter pound of the seeds. I will attach instructions according to which Lerchenbäume have been grown for many years at estates [...]. (Germann, 1807b, pp. 2-3; Sander, 2009, p. 61)

Indeed, the original larches and white pines of the University of Tartu Botanical Garden and many other manorial parks are probably derived from the seeds 
of Bauni trees. This is especially true of the larches and white pines at the von Üexkülls' estate Vana-Vigala (Alt-Fickel), Jädivere (Jeddeffer) and other manors, as in 1792 Count Sievers' youngest daughter Elisabeth had married Berend Johann VII von Uexküll (1762-1827), owner of Vana-Vigala, Haimre and other manors and founder of parks and avenues there; he would later become the civil governor of Estonia and the head of the Knighthood (Stackelberg, 1930, pp. 487-488).

Germann's trip to St. Petersburg with Count Sievers was bound with the fact that Paul I, who became Emperor of Russia in 1797, invited Count Sievers, who was already in retirement to fill the abovementioned position. However, because of tensions with the emperor, Sievers returned to Bauni in 1800 (Lenz, 1970, p. 732). Germann continued as Count Sievers' personal physician but resided in 1800-1802 near Bauni in the nearby district centre Valmiera (Wolmari) (Brennsohn, 1905, p. 171). In 1784, Hermann Johann Walter (1757-1807), who had studied at the universities of Strasbourg and Königsberg (Kaliningrad) had been appointed district physician and settled in Valmiera. He was very popular and beloved there. In 1785, he built a house, which he called Valterkalniňš. Thanks to his wife Marie Elisabeth, Walter's house soon became a centre of vibrant cultural and social life (Brennsohn, 1905, pp. 416-417; Pumpuriņ̃̌ \& Zìrina, 2019).

From Valmiera, Germann was invited to the University of Tartu as professor of natural history (Recke \& Napiersky, 1829, p. 25; Lenz, 1970, p. 238; Sander $e t$ al., 2009, pp. 542-543). There is no doubt that his education, curiosity of mind, and scientific interests made him suitable for the position.

On 6 October 1801, Germann married Juliane (Julie) Catharina von Günzel (Günzel) (Narva 1777 - Bauņi 1839) at Bauñi. In the years 1785-1793, Juliane’s father, Karl (Carl) Johann von Günzel (1741-1816), had been the governor of Vyborg, and since 1787 a lieutenant general. He was from the family of a noble from the Holy Roman Empire of the German Nation, toll inspector Christian Günzel and his wife Maria Elisabeth (née Sievers). Juliane's mother, Carl (Karl) Johann von Günzel's (1741-1816) first wife Katharina (Catharina) Sophia Hütterau (Riga 1753-1789) died young. After his wife's death, Carl von Günzel remarried in 1790, this time to Count Sievers' oldest daughter Katharina (Catharina, 1770-1844) (Krause, 1902, p. 87; Seuberlich, 1924, p. 113; Lenz, 1970, p. 276; Sander, 1018, p. 1043). The Sievers family took the motherless young Juliane under its wing, and Katharina became a second mother to her. Juliane was also close to Count Sievers, whom she called grandfather. Thus, on 11 
July 1808, a day after Count Sievers' death, Juliane writes to Karl Morgenstern from Bauni:

You are already aware of our unexpected departure from [Tartu] and you know how we feared for the life of my dear grandfather [Count Sievers]. Ah, how our horrible speculations have come true! He had a cold with acute cough, and everything was made worse by the worries about my mother [Catharina], who was very ill at the time, and grandfather insisted on tending to her faithfully. [...] How hard it was for me to hide my feelings from him [Count Sievers] when I saw the virtuous old man on his deathbed; just a few weeks earlier he had taken joy in everything amidst the happy circle in Tartu, united by science, art, and nature. (Germann, J., 1808)

Jacob Johann Sievers has stated:

As in that land I saw many poor young people continuing their studies, I deposited another capital sum of 4,000 roubles in the same [St. Petersburg] bank, the interest for which would be paid out each year to the University of Tartu Council, and transferred to the Council's administration to help subsidise the living expenses of a student in either theology or medicine, those two most important areas of study in these small Baltic lands. (Blum, 1858, pp. 639-640)

As executors of his will, Count Sievers chose his daughters Katharina, Elisabeth and Bénédickte, and his son Carl Georg. The family appointed Germann as the administrator for the stipend (2,285 roubles in silver), representing Karl Johann von Günzel's family and the University of Tartu (Tamul, 2002, p. 184; 2007, pp. 105-108).

\section{Gottfried Albrecht Germann as a lecturer and activist at the University of Tartu}

As professor of natural history and botany Germann held lectures at the University of Tartu for 12-16 hours per week (Verzeichnis..., 1815). The thrust of his lectures was general natural history, from which derived special courses. He also must have presented his observations and drawn on his own researches. Primarily, he taught general courses in natural history, zoology, mineralogy (geology), botany and the use of horticultural plants. Furthermore, he supervised 
practical works, particularly the identification of plants, and attended botanical exhibitions (displays) in the capacity of a commentator. Apart from that, he lectured specific courses, such as the natural history of Russia's birds and fauna, entomology, ornithology, etc. Germann primarily modelled his lessons on the various editions of works by Karl Ludwig Willdenow (Grundriss der Kräuterkunde) and Johann Friedrich Blumenbach (Handbuch der Naturgeschichte). The 1802 edition by Willdenow (Berlin: Haude und Spener, 644 pp.) held at the Library of the University of Tartu has evidently been Germann's personal copy. He has added an abundance of handwritten notes into the text and onto the inserts of the book, which probably are also referred to (Rand, 2015, p. 35).

Apart from the botany lessons in his capacity as the university teacher, Germann organised plant exploration trips for the students in the environs of Tartu beginning from the spring semester of 1805 ; they were continued four times a week in autumn as well, provided the weather was fair. In the spring semester of 1806, Germann carried out entomology trips (Vilberg, 1932, p. 97).

His lectures commenced on 1 May 1802. In the first semester, up until 1 July, he read general natural history for three hours and botany for five hours a week. In the autumn semester of the same year (1 August - 31 December 1802), he read zoology for five hours, mineralogy for three hours and the decultivation of horticultural plants twice a week. In the autumn semester of 1803 , he read zoology and mineralogy, both for six hours a week. Germann also guided visits to the Natural History Cabinet.

In the spring semester of 1805 , for instance, he read the general history of fauna, along with ornithology, for six hours, and botany for four hours. Botanical field trips took place in fair weather. These were continued, weather permitting, in autumn, four times a week, and included an introductory lesson on plants. In the autumn semester, the general history of fauna and mineralogy were read for six hours each. Also, botanical demonstrations were held from August to September four times a week, as were botanical field trips.

In the spring semester of 1806 , Germann lectured on the general history of fauna and entomology for six hours each and botany for four hours. In fair weather, entomological and botanical trips were made in the surroundings. In the spring semester of 1807 , mineralogy was read for six hours, botany for four hours and entomology for five hours, coupled with trips under favourable circumstances. 
In the autumn semester of 1809 , he was expected to read zoology and mineralogy for six hours.

The load of the lectures appears to have been spread evenly between botany, zoology and the history of fauna and mineralogy (Verzeichnis..., 1815).

Germann was also part of the Tartu Toome Hill Greening Committee (Plantationskommittät), established on 14 October 1803, other members of which were Johann Wilhelm Krause, Georges Frédéric (Georg Friedrich) Parrot, and Johann Karl Simon Morgenstern. On the day of its founding, the Committee also held its first session (Storchs, 1804, p. 213; Ormisson-Lahe, 2011, p. 338).

A group of professors with liberal views who converged around Georges Frédéric Parrot played a weighty role in the re-establishment of the University of Tartu. They constituted a brotherhood by the name of the Ephesian Church (Ephesische Kirche). The circle comprised 11 or 13 persons (Krause, 1902, p. 364; Loosme \& Rand, 1992, p. 24; Tohvri, 2019, pp. 487-488), including Gottfried Albrecht Germann, Lorenz Ferdinand Ewers, Daniel Georg Balk, Gottlob Benjamin Jäsche (Jaesche), the University Library director and professor of classical philology Johann Karl Simon Morgenstern, the architect of the University buildings Johann Wilhelm Krause, and others. The brotherhood was created on Parrot's initiative among a group of professors favouring the liberal worldview and endorsing the philosophical and humanistic ideas of the Enlightenment. They were united by their common stance for academic freedom in opposition to the University's board of advisors, composed of the Baltic German nobility of primarily Masonic background, who strove for dominion over the University. Therefore, it is by no means correct to consider the Ephesian Church a Masonic association, as has been suggested by art critic Juhan Maiste (Siilivask, 1982, p. 41; Tohvri, 2019, p. 488).

On 23 August 1803, Emperor Alexander I approved the ukase stipulating the rights and obligations of university students in Tartu. It was drafted by Professors Parrot, Morgenstern, Balk, Germann, and Jäsche and presented to Advisor Friedrich Maximilian Klinger, who submitted it for approval to the academic commission at the Ministry of People's Education of Russia and to Emperor Alexander I on 23 August 1803. This was part of the new notional image of the University, containing behavioural practices to be honoured by the students of the Imperial University of Tartu (Pektuhov, 1902, pp. 139-141; Tohvri, 2019, pp. 499-500). The editor of the work, according to the shared online catalogue ESTER of major libraries of Estonia, was Germann (1803, 
pp. 1-31). In the introductory part, the faculties and other institutions of the University were presented. Mention was made of the library, the museum, the natural history cabinet, the anatomical theatre, the botanical garden, the collection of anatomical and pathological preparations, the maternity hospital, the chemistry lab, the observatory, the collection of mathematical instruments and economic and technological models, along with the fencing hall, the dance hall, the equestrian arena and the swimming pool. There is also an overview of the University's administrative structure.

The first chapter dealt with the students' obligations and the rules upon entrance to the University; the second addressed the students' obligations while staying at the University - towards themselves, other people related to the University and common citizens; the third stipulated the students' agreements and loans; the fourth, academic penalties; the fifth, the students' obligations upon leaving the University; and the sixth, the students' rights. The volume ends in a note stating the identity thereof with the copy signed by His Imperial Majesty, St. Petersburg, the date 15 September 1803 and the undersigned [Advisor] Friedrich Klinger.

In December 1803, Germann, then professor of general natural sciences and botany, proposed to the Director of the University Library Karl Morgenstern to purchase some valuable scientific books from Johann Georg Schneider, a physician and a botanist. Among the 45 titles of publications on the sales list composed by the seller, three folios containing original drawings of plants stood out. Most of the drawings and supplementary notes were supposed to originate from Konrad Gessner. The valuable volumes on natural history and anatomy had reached Schneider from the library of Kasimir Cristoph Schmidel. Due to budgetary restraints, the director of the library could not afford to purchase valuable rarities, yet Schneider offered Gessner's plant drawings and several natural science publications at such an advantageous rate that on Professor Germann's recommendation the purchases were accepted. It has been found that instrumental in this deal, apart from the favourable price, was Germann's freely offered knowledge on the history of botany. Fifty roubles were charged for the historical plant drawings contained in three leather-bound volumes. The same price was asked for the luxury three-volume Illustrations of Natural History by entomologist Dru Drury, 20 roubles for Count Luigi Ferdinando Marsigli's copperplate engraving depicting 54 lichens, and 40 roubles for Georg Wolfgang Knorr's Deliciae naturae selectae. These and several other natural history volumes were purchased from the obliging seller. In May 1804, the volumes of plant drawings plus six more natural history rarities selected from the same list finally 
reached the library of the University of Tartu. Altogether, three volumes of historical plant drawings were purchased from Schneider's Hof, which contained an approximate total of 350 plant depictions (Rand, 2015, pp. 32-34, 115).

Germann appears to have been acquainted, and to have cooperated, with Benjamin Christoph Gotthilf Heidecke (1765-1811), an erudite pedagogue, publicist, translator, and publisher of various writings. Beginning from 1801, Heidecke was employed as pastor at Moscow Lutheran Church (in Neukirche). In addition, he was, until his old-age retirement, inspector of the school financed by Jacob Johann Sievers (gräflich Sieverschen Schulinstitut) operating at the same church (Napiersky \& Recke, 1929, pp. 208-210; Tsulkova, 1914, pp. 337339). It appears that Germann helped Heidecke compile some lexicon of Russia's scientists (EAA, 1806, EAA.402.4.186); the publication of which, however, has failed to be reported.

In Heidecke's edition, Germann (1808, pp. 143-145) published an interesting article on the undecayed corpses at Haljala church, discovered on his 1803 tour of Estonia. He wrote that earlier that year he wanted to acquire those natural mummies for the university collection, but the pastor would not permit that. It could only happen at that time, and he took two of the bodies along. They were situated in the University's anatomy room. Germann mentioned that according to an old legend all of the three undecomposed bodies discovered at Haljala church were female, namely the three Mrs. Lohdes. It was merely a myth, for a closer study showed that one of the bodies was male. The other, which he took along, was female. The third was generally unusable and had, for the most part, already disintegrated, and thus could not be taken along.

It appears that the corpses were already far from being in the good condition that he had observed them to be in 1803. The church's principal (Kirchenvorsteher) had exhumed them, filled the grave up again, and let the bodies stay in an open coffin or between the vestry's wooden partitions, where there was high humidity due to constant condensation on the walls. Unfortunately, the wooden partitions were against the wall, the corpses were steadily subject to moisture and therefore decayed rapidly and extensively. After some time, none of them would have remained.

Germann also mentioned of being delighted to find a note on the mummies from an old writing. According to his article, the note appeared to originate in a work by Friedrich Christian Weber (1721, p. 69), a German diplomat and writer who had served Peter the Great and had visited Estonia. The work contains a 
description of the discovery of a grave in Rakvere church, in which a noblewoman from Lohe (or von Lohe) lay in 1604 and was in the same condition in 1718. When lifted up, she felt like light timber and looked like having been entombed a couple of weeks before. As the body had never been embalmed, some attributed this miracle to the minerals in the soil. Germann writes as follows:

A fair share of the Rävala province lies on a salty soil, particularly in coastal areas. The salt stone must be the reason why natural mummies are more frequent here. I have never heard of the presence of any mummies in Rakvere church. It seems to me that the author of the piece of news has delayed in committing his notes to paper, and thus mistook Haljala church for that of Rakvere, which is only eight versts away. Also, Haljala, with its many farm buildings and the pastorate houses, looks like an authentic village. Then, the piece of news coincides with the legend in terms of the name, [...]. The name Lohe is unknown in these parts, while Lode, or Lohde, is not. (Germann, 1808, pp. 143-145)

The German name Lode or Lohde is linked with the Koluvere Castle in West Estonia and is derived from the name of the Baltic German family line there. The residence of the Stiftvogt of the Bishopric of Ösel-Wiek (episcopatus Osiliensis) in western Estonia was situated in Kullamaa, and the Stiftvogt was Johannes de Lode. The Koluvere citadel (Schloß Lode), which is close to Kullamaa, was founded in 1234-1238 by the sons Odward and Heinric of Lode. In 16461777, the Koluvere Castle was owned by the family of von Löwens (Hein, 2009, pp. 13, 26-29). However, there are no reports that a person from Koluvere had died in Rakvere or Haljala or been buried in either of the churches.

Germann had a fairly wide circle of acquaintances, which is evident from the writings of both himself and his close ones. Among the acquaintances of Germann and his wife was Gotthilf Theodor Faber (Riga 1766 - Paris 1847), a lawyer, writer, and professor of the University of Cologne, who had a close friendship with Johann Karl Simon Morgenstern. Faber arrived in Russia in 1805, was employed in the public service of the Russian government since 1813 and worked at the Russian embassy in Frankfurt from 1816 onwards. In 1808, Faber visited Tartu, where he failed to meet the Germanns, who were away at Bauni at the funeral of Jacob Johann von Sievers (Germann, J., 1808; Morgenstern, 1808; Sander et al., 2009, p. 543). 
On 1 September 1806, Germann purchased a stone dwelling with outbuildings in City District 1 from owner Maria Elisabeth v. Langhammer, widow of the late Council Member von Langhammer, for 12,000 roubles (Leng \& Lenz, 1807, p. 6). Germann's family occupied their house in 1806-1812; its present-day approximate address in Tartu is 7 Munga Street (Leppik, 2016, p. 477).

\section{Gottfried Albrecht Germann as the founder of the Natural History Cabinet}

Germann set up a Natural History Cabinet (Naturalien Cabinet) to store and maintain collections for teaching and research. It was founded on March 25, 1802, when 608 items of minerals and an animal collection in spirits arrived from St. Petersburg as a consignment of Grand Duke Konstantin Pavlovich (1779-1831). In 1803, the Saxony-Weimar mountain advisor Duke Johann Carl Wilhelm Voigt's collection of stones with a collection of $1,920(1,900)$ museum exhibits was purchased and the natural historic collections were opened to the public. The visits to the Natural History Cabinet (later Museum of Nature) were arranged by Germann. He himself collected minerals (rocks), insects and birds and his collection of insects still exists (Ewers, 1827, pp. xii-xiii; Leppik et al., 2008 , p. 6; Sander et al., 2009, p. 543). It was probably bought for the University because, at one point, a collection of insects was offered for sale by Germann's wife Juliane for a thousand roubles (Germann, J., 1811). The Natural History Cabinet procured in 1741 (1742) (also referred to as 1749) three pieces of Krasnoyarsk meteorite, found in Siberia near the Yenisei River near Krasnoyarsk (Iron of Pallas, weighing approximately $650 \mathrm{~kg}$ ), which weighed 274.2 grams. The mediator was Johann Gottlieb Georgi, a naturalist and a geographer, an explorer of Southern Russia and Siberia (1729-1802). Peter Simon Pallas found this meteor during an expedition to Siberia between 1768 and 1774 and it was analysed in his work on meteorites by Ernst Florens Friedrich Chladni (1794, pp. 39-40, 44-46; Heidemaa, 1972, p. 456; Loewinson-Lessing, 1897, p. 2; Pani, 2007, p. 128; Sobolev, 2011, pp. 68-69).

On October 4, 1804, at Germann's suggestion, the University confirmed the position of the assistant to the head of the Natural History Cabinet and an inspector. His academic friend, Ernst Markus Ulprecht (1770-1831), who studied at the universities of Leipzig and Jena, became the inspector, who also remained in charge of the Cabinet. After Germann's death, Ulprecht read lectures on mineralogy 
starting in 1810 and worked at the University of Tartu until 1813, he was a good expert on minerals (rocks) and a talented artist (Krause, 1902, p. 88; Lenz, 1970, p. 820; Vaga, 1970, pp. 52-53; Sander et al., 2009, pp. 543-544). Germann also had ties with the seafarer Adam Johann von Krusenstern, who had promised to procure plants, minerals, animals, etc. from his expeditions. At the same time, it was a priority for Krusenstern to gather them for the St. Petersburg Academy of Sciences (Pani, 2007, pp. 129; Sahk, 2007, p. 105).

Germann was also active in acquiring exposition items for the Natural History Cabinet during his longer expeditions in the Estonian province of Livonia in 1803, in the Finnish territory of Russia in 1804, and in the present-day Latvian territory of Livonia in 1806 (Sander, 2018, pp. 1045-1051). He also sought to find exhibits through hunters and nature lovers. So he gives a long account in the newspaper:

The Natural History Museum of the Imperial University of Dorpat already has a considerable collection of stuffed birds, which I have collected for the most part, also partly through exchanges from ornithologists living in distant lands. Many of the Livonian and Russian species I got on my smaller and bigger trips through different provinces of the country. But my duties bind me at the most beautiful time, when the migratory birds leave and return, to my place of stay, and the moment when the scientific hunter finds the richest prey is lost to me $[\ldots]$.

I ask every hunting enthusiast, every landowner, especially those who own land on the Baltic coast, as well as my listeners, who have been glad to watch the birth and growth of the Natural History Cabinet, and are now scattered here and there in Courland and Livonia and who have been my companions on bigger and smaller journeys of natural history, as soon as they get some rare or not quite ordinary birds, send them to me. I would especially like all types of eagles, falcons, owls, ducks, geese and other waterfowl, sandpipers, of which we have many species. Most often during their migrations, from mid-July to October on the flat shores of the lakes. Next up are the larger and smaller bog birds and gulls that stop at sea and on the coast. [...]

Occasionally the birds are of a different color than usual; for example, they often become completely white, as is the case with ravens, jackdaws, sparrows, swallows, larks, teals, and others. I would especially love these. Also, there are certainly not a few amateurs throughout the country who have parrots or other rare foreign birds that are discarded after death because people do not know how to preserve them. 
Smaller mammals would be just as nice for me as birds. I would like to have the Siberian flying squirrel (Pteromys volans $\mathrm{L}$.), they are occasionally spotted around Valmiere (Wollmar), but of course they are rare; the beech marten (Martes foina Erx.), which is also rare here, more common is the European pine marten ( $M$. martes L.), that the cabinet already has. I also want the stoat (Mustela erminea L.) and the least weasel (M. nivalis L.), the Eurasian beaver (Castor fiber L.), large and small otters: the Eurasian otter (Lutra lutra L.) and the European mink (Mustela lutreola L.), the Eurasian lynx (Lynx lynx L.) and the European wolverines (Gulo gulo L.), which according to Jakob [Jacob] Benjamin Fischer must occasionally also be found in our large forests. Particular variability such as discoloration, bastardness, etc. - the same applies to what I said about birds in this regard. However, I have to make it a condition that the animal is not stripped of its skin, but must be sent completely intact, otherwise it will not be possible to make and display the stuffed animal. (Germann, 1807c, pp. 1-2; shortened and polished)

The Natural History Cabinet was originally probably located in the Botanical Garden, from 1805 in one house with the chemistry laboratory (Leppik, 2016, p. 464) but it has been argued later that in 1809 a cabinet for mineralogy and zoology could also have been set up in the main building of the University, where Ulprecht had opened his theatrum activitatis (Krause, 1902, p. 88). In 1808, there were also three parrots living in Professor Germann's home and a Eurasian crane in the Botanical Garden (Pani, 2009). In 1809, the museum had examples of 2,000 animal species, of which 78 were mammals, 293 birds, 44 reptiles and amphibians and 53 species of fish; there were more than 1,000 species of insects (Heidemaa, 1972, p. 456; Tammiksaar, 2002, pp. 49-50).

\section{Gottfried Albrecht Germann as the founder of the Botanical Garden}

The establishing of botanical gardens at universities is linked to tradition. The purpose of their creation was to contribute to the scientific treatment of plants, their preservation and research. They were also necessary in research, especially botany as a science, and in teaching students (Kriisa, 2016b, pp. 155-158). In the University of Tartu, botany was taught at the Faculty of Medicine and Philosophy, as it was done elsewhere. 
On January 5, 1802, Russian Emperor Alexander I confirmed the lands for the university and allocated 25,000 roubles for the construction of buildings (Siilivask, 1982, p. 35). The decision to establish a botanical garden was made on December 12, 1802. The Statutes of the University (Section 126) provided for the establishing of a botanical garden under the supervision of a professor of botany, a gardener, and two workers. The professor as the garden's superintendent (Oberausseher der Gartens) was entitled to an apartment. The gardener had to provide the upkeep of the workers and horses from his own wages. In the 1803 budget, 800 roubles were earmarked for this, and 1,200 roubles for the botanical garden (Storchs, 1804, pp. 236-237, 392; Ewers, 1827, pp. xii-xviii, xxvi).

A more important task, however, was to find a suitable location for the academic garden. In Europe, the botanical gardens of universities were generally located in areas where water was easily accessible, that is, near rivers, and wherever possible, on the fertile ground of the city. In Tartu, too, it was preferable to find a plot of land by the river for the garden. Finding a plot that would comply with the requirements of the botanical garden was difficult. The main problems were either the dryness of the soil or, conversely, the plots along the Emajōgi River were too boggy. Consideration was also given to the construction of a botanical garden on Toome Hill, which the Emperor Alexander I gave to the university, but it was unsuitable for drought and poor soil (Germann, 1804, p. 333; Kriisa, 2016a, p. 27).

Johann Friedrich Kieser, an acquaintance of Germann, became the first trained gardener at the Botanical Garden of the University of Tartu. His period of service, however, lasted barely a year, and in May 1804 he was considered to be released from the service (EAA, 1848-1903, EAA.402.3.770). Subsequently Johan Peter Bueck worked as a gardener, his service also turned out to be short and he moved on to St. Petersburg. But he was a man of great soul, and despite having to leave Tartu after a quarrel, he stayed in touch and kept adding to the plant collections (Sander, 2017, pp. 45-82).

In 1805, Johann Anton Weinmann, who came from Vienna, became a trained gardener, who described his coming to Tartu as follows:

On the recommendation of my Honorable Teacher, Mr [Andreas Roman] Wolff, gardener at the Julius University Botanical Garden in Würzburg, during my stay in Vienna in the autumn of 1804, I received such a pleasant and honorable invitation from the sanitary adviser Professor Hoppe from 
Regensburg to come here to Tartu as the gardener of the Botanical Garden. (Weinmann, 1810, p. ix)

The wish for a gardener was probably mediated by Germann to his acquaintance David Heinrich Hoppe, a botanist, pharmacist, doctor and writer, founder of the Regensburg Botanical Society (1790) (Ilg, 1984, p. 8ff). Weinmann arrived with his future mother-in-law, working reasonably and with tireless zeal (Krause 1902, p. 87; Sander et al., 2014, pp. 63-66, 82-84).

On April 27, 1803, the University Council discussed the future location of the Botanical Garden (EAA, 1803-1814, EAA.402.5.52). Inspector Otto Heinrich Müller suggested one plot as a possible location, but after reviewing it turned out to be inappropriate. Germann himself had explored two possible areas: (a) Baron von Bruiningk Square, with well-maintained buildings, costing 13,000 roubles, and (b) Schwallinger's garden, without any buildings, costing 6,000 roubles, which Germann considered more suitable for the garden. At the same meeting, the Rector announced that 25,000 roubles have been allocated to the Garden and the Natural History Cabinet, but the distribution of money between them is irrelevant. Germann was given the right to buy a suitable plot. At a meeting on June 26, Germann announced that he had reached an agreement on the acquisition of a garden, formerly owned by von Pistohlkors, then merchant Jacob Johann Seebach (known as Pistohlkors garden), buildings and a greenhouse for 7,650 roubles. On September 19, the area and the buildings became the property of the University of Tartu (Fig. 2).

At a meeting on September 17, 1803, Germann announced that Baron [Klaus (Claus) Gustav von] Baranoff of Tähtvere was willing to sell land for the expansion of the Botanical Garden, asking 900 roubles for a bushel land ( 0.37 ha). He was willing to sell even more, in this case 700 roubles for a bushel land. So the decision was made to buy as much land as needed for the garden. On the plan, drawn up in 1803 and updated in 1818, the old garden is a triangular area, the north wing of which apparently extended to the Riga Road. Archival documents describe it as a location at the side of the Riga Road. The disadvantage of this location was that in the open area it was not possible to design areas on different levels and different growth areas depending on the terrain. There was also no groundwater pond, the existing one was mainly fed by rainwater. Another disadvantage was the distance of the garden from the main building of the university. However, there were good soil conditions and potential for expansion. 


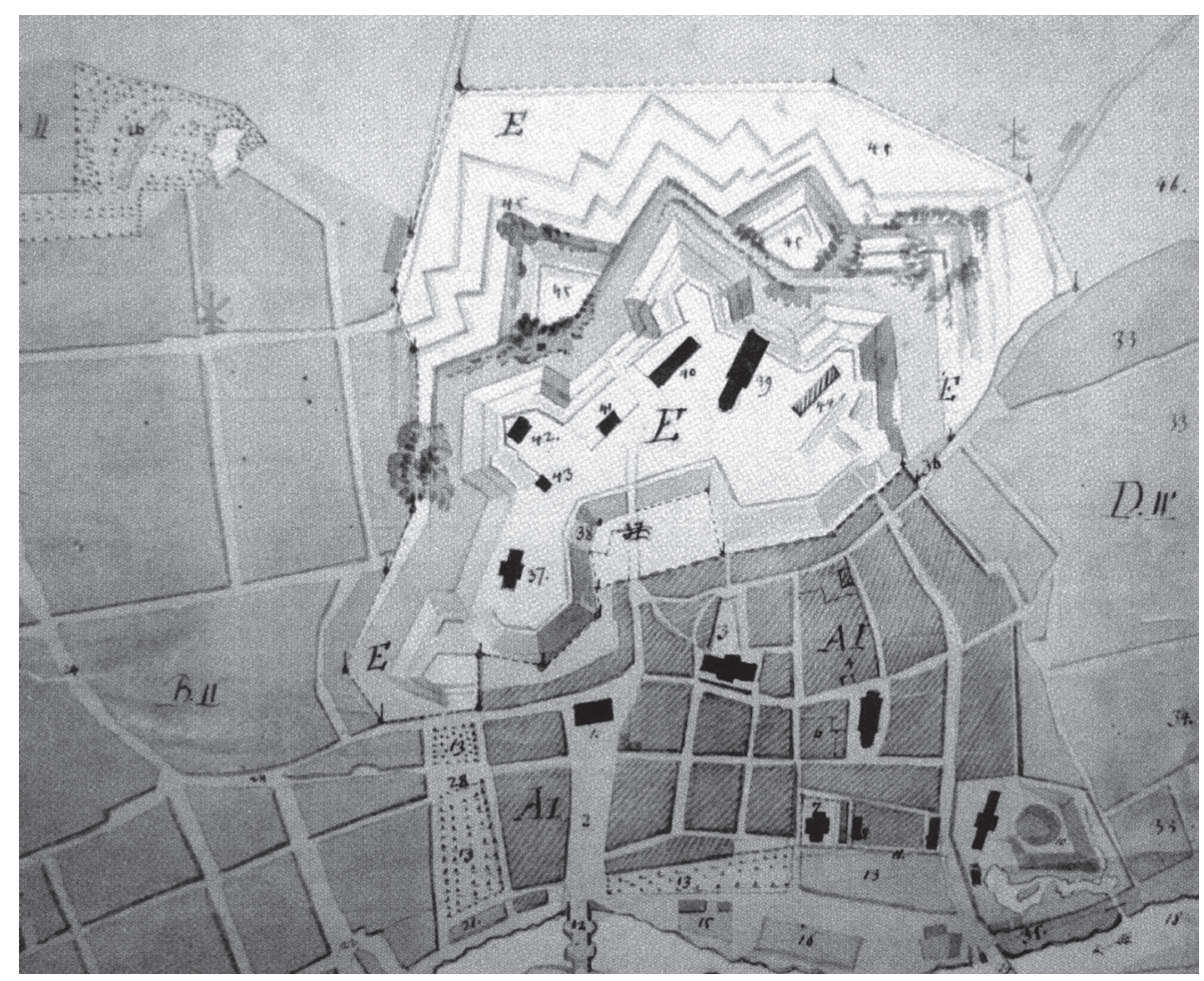

Figure 2. An 1803 plan of Tartu, updated in 1818. The first, original location of the University of Tartu Botanical Gardens is shown in the upper left corner and the second location of the Botanical Gardens in the lower right corner (Collections of the Estonian History Archives, Sander \& Meikar, 2009, p. 75).

At a meeting of the University Council on April 4, 1804, it was revealed that Baron Gustav Adolf von Rosenkampff, the State Counselor, offered to sell his plot surrounded by a wall, with a garden and several buildings, to the university for 10,000 roubles. On 14 April 1804, Germann submitted to the Council a written assessment by gardeners Carl Friedrich Bartz and Hartwig Jacob Neubauer indicating that the soil conditions in the Rosenkampff garden were inadequate, so no new land was purchased. The existing location was suitable, the land was good and cultivated; moreover, good agricultural land had been bought from Tähtvere Manor (Sander \& Meikar, 2009, pp. 74-75).

Germann wrote probably about the Rosenkampff property:

There was a beautiful garden in this town, but the owner demanded a huge sum at the time, which the university could not pay, because, together with 
the Natural History Cabinet, only 25,000 roubles had been allocated to the garden fund. The owner of this garden demanded 20,000 roubles, but I had to build plant houses and greenhouses, a gardener's dwelling, and more, how could it be done with 5,000 roubles? It also became clear that a very large part of the soil was barren and dry land. The biggest advantage this garden offered were the ponds and some hills. Hardly had we obtained all land [former Pistohlors land], as the owner, who previously wanted 20,000 roubles for his garden, suddenly lowered the price to 10,000!!! And now he offered his garden for the amount I had first wanted to give him, when we didn't have a garden yet. He hoped that the university would still take his garden, even though one garden already existed and would use the first for another purpose or sell it again—but neither method suited... (Germann, 1804, pp. 333-336)

The design of the greenhouse at the old site was presented by Johann Wilhelm Krause on March 2, 1805. Because the solution was too grand, Germann proposed new conditions for the greenhouse. On August 26, 1805, Weinmann submitted plans and calculations for the construction of the Botanical Garden and the necessary buildings, requesting that work be carried out that same year. He wanted to build a pond, a greenhouse and a gardener's house. It was decided to design a gardener's house, and the erection of the greenhouse was to be entrusted to the university's construction master, Johann Gabriel Kranhals, hired in November 1803. Krause's second drafts are dated to September 6, and the three plans, signed October 16, received the approval of the botanists (Sander $\&$ Meikar, 2009, p. 76; Kriisa, 2016a, p. 25; 2016b, p. 164).

Germann wrote about finding the original location for the Botanical Garden:

Want to know something about our botanical garden here; gladly. It was very hard to find a location for it. The Dome Hill, which the monarch gave us, was not suitable because of the dryness and poor soil; however good it was in some places, there was missing the other essential requisite, water. I was offered plenty of gardens, but most were located on marshy soil near our river, the Emajōgi River. Even if I found good places along the river, they were not for sale, in short, almost a year passed, and I still had no garden. Fortunately for me, a garden with a stone dwelling, a wooden outbuilding and, in fact, a rather poor greenhouse [the Pistohlkors garden] came up for sale at a public auction. [...] In October 1803, the garden was ours. Immediately I planted about 200 plants in the greenhouse, which I had received, had the house fixed, and in November I moved in. 
The garden had good soil, a mixture of clay and sand, and the fruit trees there grew well; it had also been cultivated for 13 years. The only regret is that everything is flat and we have no hills in the garden. But it can be easily overcome, as I have also seen some very beautiful gardens without hills. The attached field is not fenced yet, so the beautiful little lake is still outside our current garden, but before winter I hope to see the whole picture. Near the pond, next year, I will have the greenhouses built. (Germann, 1804, pp. 333-336)

Weinmann wrote about the same place:

The plot, which the blessed Court Advisor Professor Germann bought for the Botanical Gardens three years before my arrival, is located out of town on fine clayey soil mixed with sand. There are also a few dwellings, a greenhouse of six fathoms, a well and a pond.

Unbeknownst to the harsh climate and local conditions here, this place did not seem at first unsuitable for the Botanical Garden; I was only afraid of its too open position. This shortcoming was already evident when I was working on its creation. The storms, which from time to time alternate with great force from every corner of the globe, were very damaging to this facility, given its total vulnerability. Also, the pond, the main supplier of the water needed, did not have any sources that were initially promised. It was only maintained by the snow and rain water collected here. In the dry summer of 1806, I was sufficiently convinced of this.

Almost no other places around the city allow themselves to be used for this purpose, as the higher places are almost always without water and the lower ones are hindered by the annual flooding of the Emajogi River.

Now, shortly before my arrival, His Imperial Majesty had graciously allocated 33,500 roubles for the construction of new greenhouses, I was commissioned by the late Court Advisor Mr Germann to design them. As the botanical auditorium and the gardener's dwelling had to be built at the same time, I only sketched the greenhouse plan, which was reviewed and approved by the building director von Krause, the Court Advisor and knight. Already in the autumn of 1805 the whole construction site was marked with piles. All materials were delivered during the winter, just in time for the University to receive the Rosenkampff Gardens as a gift. (Weinmann, 1810, pp. ix-x)

However, on 9 March 1806, the University of Tartu received a letter from St. Petersburg stating that the wife of the State Counselor Gustav Adolf von 
Rosenkampff, Baroness Anna Maria von Rosenkampff (born Blarhamberg), was giving her garden in the northeastern part of the city wall with its stone building and everything else to the imperial University of Tartu. It appears that the garden belonged to Baroness Rosenkampff by contract dated March 9, 1806, and it was Emperor Alexander I behind the gift, because "The Emperor honored Lord R.'s much-acclaimed wife [...] with jewellery worth 12,000 roubles and the lady then donated the garden for botanical purposes" (Krause, 1902, p. 88).

The University Council began discussing the issue of the garden site on the Emajógi River, granted by Rosenkampff, on 23(26) March 1806. Rector of the University Parrot suggested that the area should first be thoroughly explored and then decided whether the present so-called Pistohlkors garden would be more suitable for the Botanical Garden or whether the garden donated by von Rosenkampff should be used instead. The reason for the immediate move to investigate the possibility of relocating the Botanical Garden was that Germann had already wanted to acquire the same site for the Botanical Garden as early as in 1802 , but at that time the property had been priced too highly. In 1804, von Rosenkampff tried to sell the garden to the University already for half the price. At the time it was decided that the property will not be purchased. The University Curator Friedrich Maximilian von Klinger was against the move, since he was satisfied with the work done by Germann and his assistants in setting up the Botanical Garden and felt that there was no need to move the garden (Kriisa, 2016a, p. 29).

Germann's report to the council on March 28 shows that gardener Weinmann estimated that the old garden can be completely redone with the money allocated, but with the new garden they will not be able to do so soon. On 3 April 1806, a comparison between the two areas was also submitted to the council (Table 1).

On April 17, 1806, the University Curator Friedrich Maximilian Klinger announced in St. Petersburg that Mrs. Rosenkampff had given the university a property with stone and wooden buildings.

Now that Baroness von Rosenkampff had finally donated the garden at the Emajôe River to the University, the Council decided to move the Botanical Garden to a new location. On May 5, 1806, Germann's report to the University Council states that the current costs of establishing a Botanical Garden have been 12,452.34 roubles, of which 7,650 roubles were land purchase, 429.84 for the buildings, additional land 4,000 roubles and other costs 372.50 roubles. Additional costs were building repairs, fencing, etc. in the sum of 6,121.51, 
Table 1. Land use of the two gardens on April 3, 1806, according to materials submitted to the University Council

\begin{tabular}{|c|c|c|c|}
\hline $\begin{array}{c}\text { Plot of Pistohlkors on } \\
\text { Riga Road (main part } \\
\text { between present-day } \\
\text { Vanemuine and Tiigi } \\
\text { streets) }\end{array}$ & $\begin{array}{c}\text { Area in } \\
\text { square ells* }\end{array}$ & $\begin{array}{c}\text { Rosenkampff } \\
\text { garden (present- } \\
\text { day Lai 38) }\end{array}$ & $\begin{array}{c}\text { Area in square } \\
\text { ells }\end{array}$ \\
\hline Garden with buildings & 31,500 & $\begin{array}{c}\text { Undeveloped } \\
\text { land }\end{array}$ & 16,400 \\
\hline Agricultural land & 52,000 & Cultivated land & 14,200 \\
\hline Other & 1,900 & Low fertile land & 12,100 \\
\hline Total & 85,400 & House and yard & 3,500 \\
\cline { 3 - 5 } & & $\begin{array}{c}\text { Water and } \\
\text { ditches }\end{array}$ & 9,800 \\
\cline { 3 - 5 } & & Total & 56,000 \\
\hline Length of the fence & 1,759 ells & $\begin{array}{c}\text { Length of the } \\
\text { fence }\end{array}$ & 1,083 ells \\
\hline & & &
\end{tabular}

Source: Sander \& Meikar, 2009, p. 76

*1 Russian ell $=0.533 \mathrm{~m}, 1$ square ell $=0.284 \mathrm{~m}^{2}$; 1 field measurement or Swedish ell = $0.607 \mathrm{~m}, 1$ square ell $=0.368 \mathrm{~m}^{2}$. It remains unclear which of the units was used.

gardening work 2,5788.53, and purchase of plants and seeds 934.6 roubles, totaling 22,086.43 roubles (EAA, 1803-1814, EAA.402.5.52). By 1806, large sums had already been spent on the construction of the Botanical Garden, and smaller problems had been dealt with. For example, Germann asked the Council how to paint the fence of the Botanical Garden and whether a coat of arms with an imperial eagle should be placed at the entrance. It has to be taken into account that the Pistohlkors plot (garden) was already in use and the general public had accepted the place (Germann, 1804, pp. 333, 344-348; Sander \& Meikar, 2009, p. 74; Kriisa, 2016a, p. 29).

However, on May 7, the Council obliged the director of the Botanical Gardens to draw up a plan about what was first needed at the new location.

The Rosenkampff [Lai Street] garden which was donated to the University, is described by Johann Wilhelm Krause, the author of the University's building projects as follows: 
Wetland and debris were the main components of the area, the demolished bastion and the marshy moat, with marshy vegetation, formed the main features. The exemplary horse stables and the chariot or wagon shed beside the wooden yard and hay barn in the originally decayed starch factory building embraced the whole constructional nature. One of the Estonian peasants had leased some cabbage beds and poor fruit trees. (Krause, 1902, p. 88)

Weinmann became responsible for designing the botanical garden in its new location (EAA, 1805-1828, EAA.402.3.276). The construction of the glasshouse commenced at the new site in 1806. On 5 October 1807, Krause proudly informed the Rector of the University that the glasshouse was finished: "Die Botanis. Treibhäuser werden heute, Sonnabnd den 5te Octobr. Fertig". The transfer ceremony took place on 8 October 1807. The attendees included Krause, Rector Carl Friedrich Meyer, Professors Georg Friedrich Parot, Martin Ernst Styx and Friedrich Eberhard Rambach, Director of the Botanical Garden Gottfried Albrecht Germann and chief gardener Johann Anton Weinmann. On behalf of the University Council, Rector Meyer presented Weinmann with a symbolic gift of one silver basting spoon and twelve silver tablespoons. The construction of the Botanical Garden was finished in December 1811 (Kriisa, 2016b, pp. 162, 165) (Fig. 3).

Besides, the chief gardener of the Botanical Garden Weinmann lived in his official apartment in the Botanical Garden in 1810. In addition to his wife, child, mother-in-law and two domestic servants, his household comprised three gardener assistants (Leppik, 2016, p. 473). The planned buildings of the Botanical Garden and the construction and description of the greenhouse and other buildings, together with the vegetation richness at the new location of the garden, have been published in detail (Weinmann, 1810, pp. ix-xvii, 1-169; Ewers, 1827, pp. 40-44; Maiste \& Ormisson-Lahe, 2016, pp. 177-188).

The positive side of the new garden was its location within the city and the proximity to the university's main building, the varied terrain, wind protection and water abundance: the moat requiring regulation and the proximity of the River Emajógi. The disadvantage was the lack of useful surface area: the area included about one hectare of ruins and the bastion embankment, also the excess water. In 1822, an adjacent garden plot was purchased and in 1824 the soil between the River Emajogi and the moat was filled. As a result, the area of the Botanical Garden increased to 84,966 square ells (3.2 ha) (Ewers, 1827, p. 40). 
The Life and Activities of Professor Gottfried Albrecht Germann, the First Natural History Professor at the University of Tartu

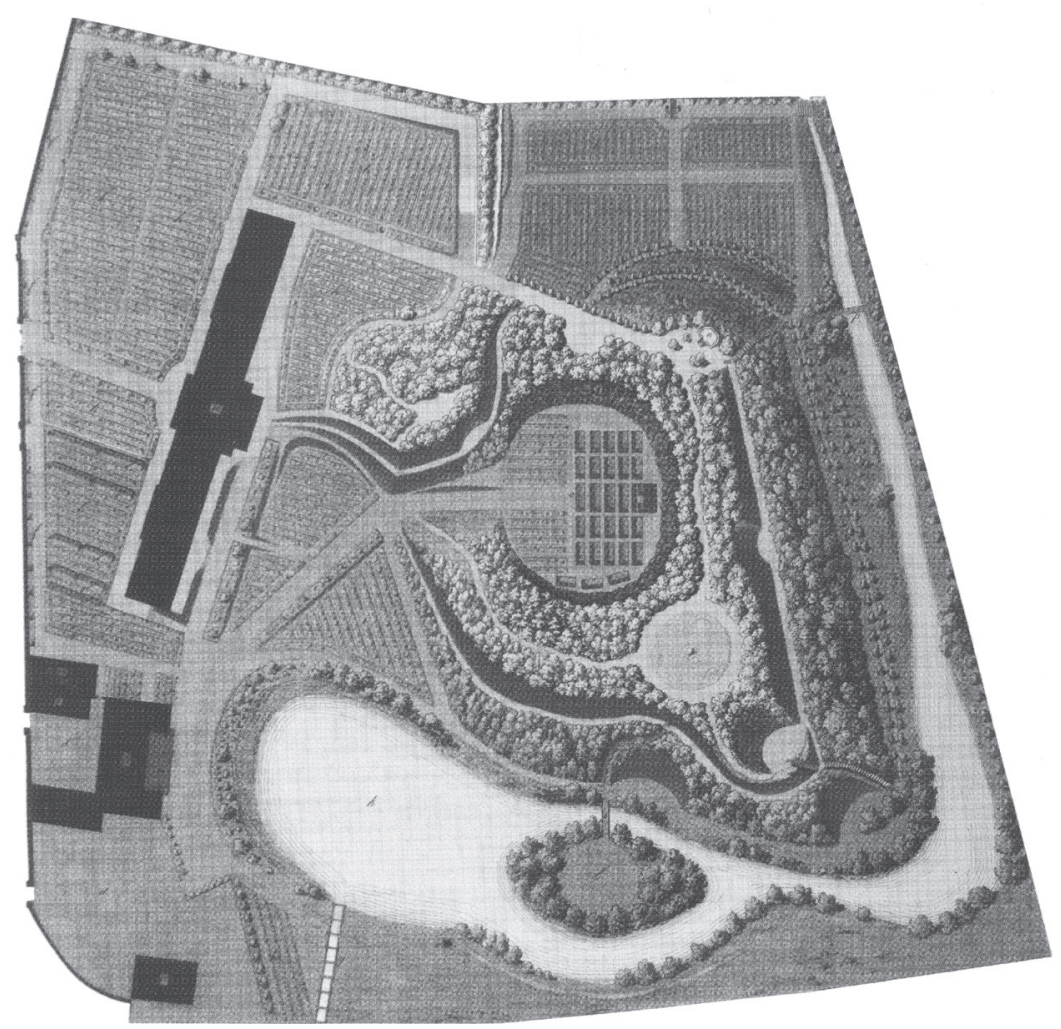

Figure 3. Layout of the University of Tartu Botanical Garden in its present location (Ewers, 1827, Plate XVI; Sander \& Meikar, 2009, p. 77).

In September 1808, Germann announced that the Botanical Garden had completely moved out of its old location and the former garden was put up for auction. Formerly on the Pistholkors family plot, the Botanical Garden had two five-room dwellings, one of stone and one of wood, a cellar, a wagon shed, a stable for eight horses, and a greenhouse. A greenhouse with four heated rooms and a fence with a gate were also built. The land was bought by the University's legal officer, Peter Georg von Ungern-Sternberg, and the proceeds went to cover the costs of the new botanical garden (Sander \& Meikar, 2009, p. 77; Kriisa, 2016a, p. 30; 2016, p. 161).

The gardener Weinmann played a particularly important role in the planning and construction of the Botanical Garden at the new site, and under his guidance in autumn 1808 the plants of the old site were transplanted into the new garden. 
With Professor Germann preoccupied teaching responsibilities, Weinmann had to bear the main burden of creating the Botanical Garden. Therefore, one might think that the gardener could do quite a lot at his own discretion (Sander $\&$ Meikar, 2009, p. 82; Kriisa, 2016a, p. 30). Weinmann himself wrote about his work on the new Botanical Garden as follows:

Shortly thereafter, I was presented with the current location; and from then on, I maintained two gardens until the current one was so advanced that I could liquidate the first; this liquidation did not go without difficulties. At that time, I sketched some plans for the current greenhouses, one of which was adopted with some modifications. During this construction, I guided everything and had to walk from one end of the city to the other twice daily, not infrequently with tired limbs. Building the current garden, however good or bad it may have been, was one of the most daunting jobs I could ever get; under the conditions that were then, I would not do anything like that again, because I sacrificed some of my otherwise flourishing health; I got unpleasant gout. For almost three years I worked without proper help and operated only with ordinary workers. [...] I shall skip the rest and just say that besides the day job, I sowed everything alone and transplanted everything with my hand.-This is how the botanical facility was created here in seven years. (Weinmann, 1810)

To conclude this topic, here is an account of the Botanical Garden by a Courland traveller from the year 1814, thus four years after its establishment. As far as is known, it is the first overview of its kind, presented through the eyes of a foreigner:

The botanical garden, along with its buildings, ranks among the most beautiful and elegant institutions of the University. The garden stands out by both its location and the large numbers of domestic and exotic plants.

The shaded alleyways, green lawns, groves of tall ash-trees provide for the most delightful walks, and the serene sit-down sites of the countryside attract the weary and prepare them for further delight. Exceedingly charming and scenic is the view from the high steep terrace to the gorgeous Emajogi River valley, which embraces a section of the city with adjoining gardens and planted trees. Hills and hillocks, partly covered with trees, partly bearing residential houses, rise on the other side, encircle the valley and line the banks of the leisurely river. The hilltops are adorned with several windmills and cathedral ruins, which seem ever so beautiful, particularly when viewed 
from this side, because they show the horizon between the solitary pillars and the arches above. [...]

The precincts of the garden include a number of botanical glasshouses and buildings serving as dwellings for gardeners and labourers. Their construction cost 57,226 roubles. I am too wretched an expert to be able to tell you about the rarest plants here. I was especially fascinated by a couple of trees that seemed to belong to the genus of palms. They were situated in a glasshouse, which housed a beautiful auditorium in the centre for lectures by the botany professor. (Schlippenbach, 1818, pp. 45-46)

\section{Gottfried Albrecht Germann as a scientist_ornithologist and botanist}

While working as a medical practitioner with Count Sievers, Germann apparently had to travel and move his household along with him. Consequently, he had not much time to occupy himself with his main interest, ornithology, which had fascinated him first, after his studies in Germany. He probably enjoyed the years 1797-1798, when he lived at Count Sievers' manor at Bauni. The heart of the manor is situated close to the southwest shore of Lake Burtniek (Burtnieks in Latvian), which is the fourth largest lake in Latvia, lying in the northeastto-southwest direction (area 40 square $\mathrm{km}$, depth $4.1 \mathrm{~m}$ ). The lake feeds on the influx of 23 rivers and has only one effluent, that of Salatsi. At that lake, Germann made ornithological observations. Neither did he forget ornithology in later times, during his employment at the University of Tartu. How much time he had for it, however, is another matter.

In ornithology, Germann's work was highly appreciated by naturalist Bernhard Meyer (1767-1836), who used the data obtained from him to compile an overview of the birds of the Baltic provinces (Meyer, 1815, pp. 1-282). Meyer wrote:

Germann was an indefatigable ornithologist, who could undoubtedly have been able to do much more for ornithology had not death torn him away from this world in his prime. I corresponded with him on natural history for more than ten years, and thanks to his friendship have many rare birds in my office. His contribution to ornithology is of great value. (Meyer, 1815, p. viii) 
In the introduction to his monograph on birds, Meyer writes:

Just before his death, Court Advisor and Professor Dr. Gottfried Albert Germann in Tartu sent me his writings on the ornithology of Livonia and Estonia for the purpose of printing them as a publication, provided I find them suitable. They only contained a few appreciable observations and notes. In sum, the writings represented a list of the birds encountered in the respective countries, with no definite identification marks of the species; the marks had only been added to the species that Germann regarded as new and that were until then undescribed. Unfortunately, there were no new species among them. Concerning the habitats, nutrition or procreation, some mentions were made only to an occasional bird. (Meyer, 1815, pp. vii-viii)

On the other hand, it appears that before his death, Germann sent his description of birds, with detailed side notes, to his friend Pastor Friedrich Erdmann Stoll (1761-1826) of Jaunpils (Jürgensburg). Stoll supplemented it with the observations of many others and made multiple copies thereof. He edited all the material, and this became the foundation of Meyer's quality monograph on the species composition of the birds, and the natural history data concerning Estonia and Livonia. It appears from Meyer's work (1815) that Pastor Stoll lived at Germann's place for a number of years and passed on to both him and Meyer many observations and notes relating to the birds of Livonia and Estonia, and in general contributed greatly to the work issued by Meyer. Thus, there appears to be some confusion here. Nevertheless, Germann and Stoll did cooperate.

Germann had time to publish only one ornithological article, 'On a Nordic seagull species' (Germann, 1809, pp. 240-248). He collected material for his article on seagull from the vicinity of Lake Peipsi during his Tartu period, but he also had his observations from Lake Burtniek and other locations.

In the introduction to the article, Germann writes: "The story of seagulls is still so obscure and undefined that an introduction of just one species to the ornithologists is quite a feat. Their appearances, their several-years-long colour changes present difficulties that can only be surmounted by years of observations." (Germann, 1809, pp. 240-248) Then he presented the views of a number of naturalists in connection with the description of the seagull species under study. The object of the study was the Russian common gull (Larus canus heinei Homeyer 1853), which is larger than the nominate form and has a more eastwardly spread, beginning from Lake Peipsi and southeast Estonia and ending with the Lena River basin in the east. The presented description of the adult 
bird suggests that Germann noted the contrast dark on the specimen's ash-grey back and, more widely, the black pinion ends, which indeed are the primary distinction marks of the subspecies. In the writing, we find several descriptions of the seagulls' behaviour as well as the portrayals of their habitats.

I know my seagulls at every age; I have seen them assembled in groups of several hundred, observed them for days on end on the hatching sites; I have also shot them several times when their young were already fairly big. I have stuffed four specimens of different ages for the academic natural history museum, and can, as soon as I have the possibility, to procure some more and stuff them to send them to my German friends, the ornithologists, if necessary. (Germann, 1809)

The author was able to see his article published in spring 1809 in the first volume of the annals of the Wetterau Society for General Natural Sciences, founded in March 1808 in Hanau, Great Duchy of Hessen-Darmstadt. It is one of the first natural sciences associations in Germany, whose list of honorary members also includes Germann. It may also be that the headings of the lists of honorary members and active members were mixed up because, first, the sorting of the list seems unusual — the active members coming first—and, second, the honorary members far outnumber the active ones.

Germann's botanical research proceeded along two lines. Primarily, it dealt with the studies of the natural flora of the provinces of Estonia and Livonia and was also connected with the establishment of the Botanical Garden of the University of Tartu and the compilation of its plant catalogue. The latter became the ultimate masterpiece (Germann, 1807a), which, apart from the foreign species, registered our own native plants collected to the garden, with their exact natural sites recorded. Germann himself wrote upon the publication of the botanical garden's plant collections:

I trust that with this list I have presented by no means an insignificant supplement to the flora of Livonia. In addition, I have often named the sites where the rare plants of Livonia and Estonia were discovered. On my annual trips, I hope to add even more marks and in the future collect the exhaustive material on the flora of the area. (Germann, 1807, p. viii)

Unfortunately, the work remained unfinished. At the same time, a fairly profound and pioneering study of the flora, mainly that of Tallinn and its environs by Johann Sverdsjoe Jr. (Sverdsjö, 1759-1809), had already been carried out before 
him. Sverdsjoe had studied at the University of Uppsala and been a teacher at the Tallinn Grammar School, a deacon of the Tallinn Mihkli [St. Michael's] Church and a deacon and chief pastor of the Niguliste [St. Nicholas' Church (Aarma, 2007, p. 262). The study compiled by him, along with many drawings, is still undiscovered, as is the list of plants that Sverdsjoe showed to Germann. The manuscript was sent to Leipzig and went missing there. Botanist Gustav Vilbaste made an unsuccessful search of the manuscript in the 1930s at Niguliste Church and in the archives of the cities of Tallinn and Leipzig. Neither did an inquiry to the archives in Leipzig in 2014 yield any results (Germann, 2018, fn on p. 1027).

In 1803, when Germann met Sverdsjoe on his trip to Estonia, he was apparently shown a list of 800 plants that Sverdsjoe had surveyed in the environs of Tallinn.

The pastor had already compiled an overview of Tallinn flora years ago and presented it to the local bookseller [Peter Gottlieb] Bornwasser, but the latter has procrastinated the printing year in and year out. The book is still not published, and apparently never will be by Bornwasser. Why has noble Sverdsjoe not written a novel or a short drama? Mr. Bornwasser would never have delayed so long with one of them! (Germann, 2018, pp. 1027-1028)

If viewed critically, Germann might himself have supported the publication of the work at Michael Gerhard Grenzius' print shop in Tartu, which had operated since 1789. After the reopening of the University, the print shop also started to provide services to the University.

\section{Gottfried Albrecht Germann's travels during his Tartu period}

\section{Travels in present-day Estonia}

In summer 1803, Germann undertook an expedition to the territories of Estonia and Livonia along with two university students whose names are unknown (Germann, 1805a, pp. 57-104; Vilbaste, 1939, p. 6). Neither is it known whether he had ever been to Estonia before taking the position at the University of Tartu. Possibly he had not, and so this was an expedition to familiarise himself with the area while gathering plants for the herbarium and shooting birds for stuffed specimens for the Natural History Cabinet. This was the first expedition 
to Estonia ever to be led by a natural scientist and certainly the longest one over the years; his travelogue provides the first extensive overview of Estonian flora to be circulated abroad.

What map Germann used is not known for certain, but there were not too many options, since Otto Friedrich von Pistohlkors' map from 1783 was too general and did not display roads. Thus, his guide was most likely the atlas by Ludwig August Mellin. On his trip, Germann carried a hunting rifle and took a birding dog along. Stops were made at manors, pastorages and taverns; also, various kinds of lodgings were available in towns. On the journey, Germann registered 100 plant species which he gathered for the herbarium. In his travelogue he introduces the pastors he met who had botanical interests as well as their achievements; to a lesser extent he discusses the natural surroundings and local conditions. The trip took 35 days, from 30 June (12 July) to 3 August (15 August) and covered over 100 German miles (over $890 \mathrm{~km}$ ). The journey traversed the whole of Estonia. From Tartu the way led to Mustvee on the shores of Lake Peipus; from there to the Voka Manor and onward northeast to Narva. The travellers also visited Narva-Jóesuu and then returned to Voka; on to Rakvere, followed by Tallinn, where they spent three days. Paldiski was next, followed by Haapsalu, Lihula, and Pärnu; in the south they spent two days at the Ôisu (Euseküll) estate, visiting its owner, August Friedrich von Sivers (1766-1823). In the lovely deciduous groves of that area, Germann recorded a large number of Cystopteris frangilis (L.) Bernh. (Polypodium fragile L.), Actaea spicata L. and Angelica sylvestris L. On 12 August, near the manor by the Oisu Lake he found a few examples of Caltha palustris in bloom. From Ôisu the travellers made their way via Viljandi to Póltsamaa, where they met Pastor August Wilhelm Hupel, and then proceeded to Tartu (Germann, 1805a, pp. 57-104; 2018, pp. 1013-1041).

\section{Travels to the Finnish area of Russia}

In summer 1804, Germann made his longest journey, with Finland as the destination. He was accompanied by six university students. He was allotted 300 roubles for the journey (Storchs, 1806, p. 25). The diary of Johann Luwig Jochmann (1785-1814) (Sander, 2018, p. 1047) reveals that there were many participants in the expedition, among them students of medicine and theology_-Johann Georg Grube (1785-1854), Heinrich Klappmayer (1781-1851), Heinrich Christoph Rinne (1781-1864) or Friedrich Wilhelm Rinne (1783-1863), Wilhelm Woldemar Schulz (?-1806) and Carl Wilpert 
(1785-1861) (Hasselblatt \& Otto, 1886, pp. 5, 6, 7, 8; Sander, 2018, pp. 1047-1049). It must be noted that the student with the last name Rinne was most likely Heinrich Christoph Rinne, student of medicine, and not Friedrich Wilhelm Rinne, student of theology.The journey took eight weeks and covered approximately $2,050 \mathrm{~km}$. We get a very general overview of the expedition from Germann's (1804, pp. 328-333) travelogue and Jochmann's (1804) diary. The first diary entry was made on 10 June 1804 and it says that the journey began the following day, on 11 June, in two wagons, with the goal of driving via Torma to St. Petersburg. There the travellers spent some time sightseeing and continued on to Lake Ladoga. The diary provides an overview of the lake, its islands and the surrounding area, and the last entry is from 18 July. Germann has himself written a very brief account of that trip. He highlighted an occasional plant, wrote to the German apothecary, physician and botanist David Heinrich Hoppe that he would be pleased to exchange seeds, and added that he had a fair amount of seeds and a plentitude of rare plants. Specifically, Germann mentions Aconitum lycoctonum L. subsp. lycotonum (Aconitum septentrionale Koelle), which he spotted in the region of Ruskeala marble mines close to the Swedish border. He wrote:

Unfortunately, it was still in early bloom and I could only gather an occasional sample; however, I took along rather many seeds for our botanical garden and our German friends. [...] It was growing in huge quantities by the roadside in limy soil, the blossoms being always of a pale purplish-bluish colour and the lower leaves large and powerful, the size of a platter. How could Linné mistake this plant for var. lycoctons is puzzling me: even its petal (galea) is larger. (Germann, 1804, pp. 329-330)

In a spacious swampy area in Finland, Chamaedaphne calyculata (L.) Moench (Andromeda calyclata) was discovered. It appeared to have started blossoming for the second time in July, presumably due to the extended heat wave in the area: the temperature in Finland was alleged to be $40^{\circ} \mathrm{C}$, occasionally even $42.5^{\circ} \mathrm{C}$, in the sun. At the end of his piece of writing, Germann said:

Finland is very rich in mosses and lichens. I would undoubtedly have picked up quite a few specimens from the low rocks, but unfortunately I had not outfitted myself with a sufficient supply of little boxes and other means of preservation. However, I will certainly go to this romantic country again, and then I will gather quite a little. (Germann, 1804, p. 333) 
Germann intended to revisit Finland in 1805, but the resignation of the chief gardener of the Botanical Garden Johann Peter Bueck in late 1804 or early 1805 left the garden with nobody in charge of practical works. Thus, the entire endeavour of developing the garden then rested on Germann's shoulders, until in 1805 Weinmann arrived to take over (Levitskiy, 1902, pp. 343-344; Sander et al., 2014, pp. 63-66; Sander, 2017, pp. 61-63; 2018, pp. 1047-1049).

It has been suggested that in 1803, 1804 and 1805, Professor Germann, along with some students, was sent to the provinces of Estonia, Livonia, Finland and Mogilev to compile natural history collections for the University's Natural History Cabinet (Petuhov, 1902, p. 268). Hence the speculation about Germann's trip to the Mogilev province (founded anew in 1802), which, however, is uncorroborated by any other known report or record.

Germann also had other travel plans: "Next year he plans, si Diis placet, to visit the Crimea" (Anon., 1804, p. 367). From a botanical perspective such a trip would certainly have been more interesting than the Nordic countries, and it was also Germann's secret wish to become acquainted with mountain plants. It is also possible that travelling to the Crimea had to do with Germann's friend Christian Steven, botanist of Finland, Sweden and Russia, with the intent of studying plants there together. However, in 1805 Steven was not yet active in the Crimea, and was instead on a research trip to Georgia and its surroundings (Nordmann, 1865, pp. 104, 108).

\section{Travel to St. Petersburg}

In August 1804, Germann went to St. Petersburg to procure seeds and live plants for the Botanical Gardens of the University of Tartu (Germann, 1805b, pp. 17-32; Sander, 2018, pp. 1049-1051). His account of this trip was published in the fourth volume of the journal Flora oder Botanische Zeitung, with the entire volume dedicated to him, with the following acknowledgement printed on the page following the title page of the volume:

Ihrem würdigen Ehrenmitgliede dem Herrn Dr. Germann, Russ. Kaiserl. Hofrat und Prof. Der Naturgeschichte zu Dorpat, Director des Bot. Garten deselbs, und Mitgliede mehreren gelehrten Gesellschaften widmet den vierten Band der Botanische Zeitung die Botanische Gesellschaft Regensburg. 
Germann wrote that it was fashionable among the rich estate owners of Russia to cultivate in their greenhouses and winter gardens the rarest and most expensive plants from the remotest regions. The majority of such live plant collections were located in St. Petersburg and Moscow and in their environs, but large plantations of greenery were no longer uncommon in outlying provinces either. Shiploads of plants from abroad arrived at ports. Among the leading botany enthusiasts of Livonia he mentions Christoph Burchard von Vietinghof-Scheel from Alüksne (Marienburg), Count Johann Gottlieb Münnich from Luunja (Lunia) near Tartu and Reinold Wilhelm von Liphart of Raadi (Ratshof) Manor (Germann, 1805b, pp. 22-23; Sander, 2018, pp. 1049-1051). More than 1,000 designations of ornamental plants were observed at Alūksne (Schmidt, 1800, pp. i-xxv; Buek, 1804, pp. 1-14). Raadi was the only manor in Estonia to supply 64 species to Eduard Lindemann's herbarium. The Botanical Gardens of the University of Tartu had supplied 2,500 species. Material for the herbarium was collected by his father Emanuel Lindemann in 1814-1820, mostly while studying at the University of Tartu (1814-1819) (Lindemann, 1863, pp. 234, 236). For some reason, Germann failed to mention the manor of Bauni, which he was familiar with and which held thousands of species of ornamental plants already in the 1780s (Baltinšn, 2006, p. 123). Here, like in Alūksne, the English park style was dominant.

Germann compares the ornamental gardening and horticultural fad of his time on the example of Camellia japonica L.:

Here [in St. Petersburg], one is often bewildered when German papers label as rare and expensive some plant that has long before ceased to be a rarity in our parts. Thus, we laugh - to give just one illustration — when we read in the news that somebody somewhere has seen what is claimed to be really rare: Camellia japonica. In our parts [Russia], this beautiful plant is far from being a rarity; it is found in any major glasshouse, and all the horticultural traders offer it for sale. In Livonia alone, I know of five places where this Camellia can be seen. (Germann, 1805b, pp. 22-23)

Back then, the species was also cultivated in the glasshouses of the Botanical Gardens of the University of Tartu (Germann, 1807a, p. 32).

In St. Petersburg, the most notable gardener was Ludwig Marseille, who eclipsed the other plant traders in terms of reliability and choice. Marseille's 1804 plant sales catalogue contained approximately 1,625 species, of which only a few were of European provenance (Germann, 1805b, p. 27; Sander, 2018, p. 1050). Yet it was far from being exceptional. Germann had to keep an eye on Johann 
Hermann Zigra's (1805, pp. 5-42) nursery, established in his hometown Riga in 1798 (Recke \& Napiersky, 1832, pp. 591-594). According to the nursery's catalogue, 1,696 species and varieties (the plant names are partially overlapping) from around the world were cultivated in and out of the glasshouses; for these, frost-resistance has been indicated in 1,437 instances. In addition, there were 150 varieties of roses as well as apple, pear and cherry trees and lemon, orange and bitter orange trees, among others (Zigra, 1805, pp. 39-41). As is typical of English-style parks, there were references to 158 tree and shrub species of North American provenance alone, along with their cultivars, as well as to their frostresistance (Zigra, 1805, pp. 36-40). Furthermore, the designations of the plant species mentioned show that the nursery included trees and shrubs of European and Asian provenance as well.

Summing up his trip to St. Petersburg, Germann recounts an amusing episode related to ornamental plants:

Finally, let me tell you another botanical joke about how some Russian counts spend their money and what they end up receiving for the largest of sums. In Moscow, where the desire to operate such plantations is the greatest, one of such rich men took some of his friends to his glasshouses one day. Here, the shelves held the most heavenly and fragrant plants. The landlord felt immeasurably flattered by the recurring shouts of surprise from the lips of his companions: "This I do not have; this is alien to me!" And indeed there stood on the highest shelves only unprecedented plants alien to Moscow, flaunting their heavenly blossoms. Among the companions there was a learned botanist. For him, some things were so extraordinary that he decided to subject them to scrutiny. So he did, and discovered that the plants that were placed the highest, the closest to the roof of the glasshouse, were actually artificial! The gardener had them prepared by Moscow hatters and thereby made his life easier. The story may well be true, as a few years previously a prominent Russian had a massive library, which was actually composed of waste paper, yet made quite an impression in the locked showcases under the most exclusive titles. (Germann, 1805b, p. 32) 


\section{Travels in Livonia}

Ostensibly, Germann often went on natural history hikes in the Baltic region; beginning in 1805 he did so almost every summer (Levitskiy, 1902, pp. 343344). Germann himself wrote:

In the future I plan to significantly cut back on my annual excursions or put an end to them altogether, for the expenses are a bit too high for me to bear alone, and I do not always have the chance, as was true for some of the previous years, to share them with someone else. (Germann, 1807a, p. ix)

Germann seems to have had a good working knowledge of Livonia. When living and working in Bauni (he travelled there later as well) and in Wolmar, he travelled a great deal in the area. For example, on the topic of common ivy (Hedera helix L.), he notes that, according to Jakob Benjamin Fischer, this species should be found in Livonia, with the reservation, "I have yet to see it myself, even though for many years I have travelled through the area and visited our deep woods" (Germann, 1807a, p. 67). Of course, Germann knew the area around Riga, the city where he was born. We can see from the plant catalogue of the University of Tartu's Botanical Gardens that Germann had been on the banks of the Koiva River and visited Sigulda (in German Segewold) as well as the garden of Diklu (Dickeln) manor, which belonged to von Tiesenhausen (Germann, 1807a, pp. 44, 51, 113-114) and where he found bog cloudberry (Rubus arcticus L.). Clearly, he also visited Alūksne (Marienburg), because he writes that he had personally acquired an allotment of beautiful plants for the University's academic Botanical Gardens (Germann, 1805b, p. 24). However, it is not always clear whether the plants were registered during the time Germann was working at the University of Tartu or before that, or whether Germann used other sources (for example, he mentions Jakob Benjamin Fischer and David Hieronymous Grindel). Germann also received plants from correspondents. It is also known that in 1805 he visited Setumaa in the Pskov governorate, and among the trees growing there he mentions common dogwood, Cornus sanguinea L. (which also grew in Sigulda on the banks of the Koiva River); in the ruins of the Irboska castle he also found Cotoneaster scandinavicus B. Hylmö (Mespilus cotoneaster) (Germann, 1807a, pp. 44, 88).

In 1806, Germann made a longer trip in Livonia, to the territory of presentday Latvia, of which relatively little is known. He went to Riga, to the RigaËrgli road and to the Lielkangari (Grosse Kanger) uplands in the basin of the Mãza Jugla River, the highest part of which is up to $7 \mathrm{~km}$ in length and 10-27 
$m$ in relative height. Thereafter he visited areas by the Daugava (Düna) River, with the following riverside places being mentioned: Koknese (Kokenhusen), Alteni (Altona), Sece (Setzen, Sezzen; further away from the river) and Pḷavin, (Stockmannshof). Judging by the number of plants recorded by him, he explored the last four areas at greater length (Germann, 1807a, pp. 14-16, 51, 64-65, 76, 82, 109, 124, 133, 136; Sander, 2018, pp. 1046-1047). Concerning Riga, he writes the following about Silene chlorantha (Willd.) Ehrh.:

Last summer this lovely plant enriched the variety of flora from Livonia that I found on my excursion there, as well as our garden. I found it in the dunes along the Väina River, not far from the imperial garden. The green flowers close their blossoms at night and they are extraordinarily fragrant. I was surprised that [Jakob Benjamin] Fischer, who lived for many years in Riga, had not noticed Silene, which grows to a height of two or three feet! (Germann, 1807a, p. 124)

From Lielie Kangar hills, located between Ropaži (Rodenpois) and Suntaži (Sunzel), Germann reports finding Dracocephalum ruyschiana L. and Fragaria moschata (Duchesne) Weston (F. elatior Gay):

Last July, while on an expedition, I found out that garden strawberries grow in Livonia. Until then I did not know their original homeland, and when I inquired, [Carl Ludwig] Willdenow suggested America. I found them in abundance at Suur-Kangeri on a chain of hills about one German mile in length, where they grew to the height of 10-14 inches. It is not possible that they spread from gardens to this horrible wild natural environment, where for miles on end there is no house to be seen, let alone a garden. I found the largest and loveliest specimens in the shade of a high bush. I also found out later that in Livonia and Estonia one can find them in several places in large forests. Their so-called fruit ripens much later than that of common strawberries. These are much larger, more oblong, and have sharp tips. I was still eating them in the first days of September, long after the common ones had disappeared. (Germann, 1807a, pp. 54, 61) 


\section{On the development of plant collections}

Germann wrote about how he obtained plants for the botanical gardens:

The gardens received noteworthy contributions from Germany and exotic seeds from Vienna and Würzburg, as well as some from Berlin; several hundred species from Count Razumovski's garden in Gorinka near Moscow, as well as some from London and Kharkiv. For three years already, my dear, faithful old friend, Privy Councillor Steven has been supplying us with seeds from northern Caucasia and other parts of southern Russia. I would also wish to publicly thank the pharmacist Stählin (Stehlin) from Sarepta, who procured some unusual and lovely seeds from the area. (Germann, 1807a, pp. 5-6)

Aleksei Kirillovich Razumovski (Rasumovski, 1748-1822) was Russia’s Minister of Public Education, president of the Moscow Naturalists' Association (founded in 1804), and an amateur botanist. He founded a botanical garden in Gorenski and developed it into a scientific institute. The garden's first director was Christian Friedrich Stephan (1757-1814). At the beginning of the 19th century, the garden was Russia's most important centre for studies in botany. Christian Steven (1781-1863), a botanist born in Helsinki, studied at the University of St. Petersburg and worked in northern Caucasia, Georgia and the Crimea. He was the founder and first director of the Nikita Botanical Garden (1812). His plant collection was the basis for the herbarium of the University of Helsinki's Botanical Museum. Sarepta was a former German colony in southern Russia, currently within the boundaries of the city of Volgograd (Sander \& Meikar, 2009, p. 83).

Weinmann wrote:

The late Privy Councillor Germann had purchased a small portion of these seeds from Riga and St. Petersburg; however, most of them were acquired by my predecessor J. P. Bueck, who brought the seeds with him when he assumed his post. In order to continue building the collection step by step and as inexpensively as possible, particularly when the garden's other pressing needs lay claims on the annual allotment of 1,100 roubles, I set myself the goal of finding friendly benefactors. As I also needed to purchase some plant species that needed to be ordered, I economised on the assistant's wages. This year I was happy to be able to make one or two purchases. The garden was notably supplemented thanks to Mr Rosenthal from Vienna, gardener for His Excellency Count von Razumovski, who gave me the gift of several 
hundred species of seeds on the occasion of my departure from the assistant's position there. (Weinmann, 1810, p. xiv)

Count Andreas Razumovski (1752-1836) was a Russian diplomat who served in 1777-1779 at the Russian Embassy in Vienna, and from 1784 on as the Russian ambassador in Vienna. Konrad Johann Rosenthal (1769-1843) was a famous Viennese landscape architect, designer of city avenues, the gardens of noble families (including that of Count Razumovski), the Pötzleinsdorf castle park, as well as various arboreta.

Botanical material was sent to Tartu by Europe's most famous as well as lesserknown botanists (Weinmann, 1810, p. xiv; Sander \& Meikar, 2009, p. 84). Johann Jakob Bernhard (1774-1850), who studied at the University of Erfurt, was later professor of botany and director of the botanical garden there until the end of his life. Through collection and exchanges he established a 60,000 leaf herbarium consisting of American, Asian and African plants. Friedrich Ernst Ludwig von Fischer (1782-1854), a Russian botanist born in Germany, was the third director of Razumovski's Gorenki garden (1806-1822), compiled plant catalogues for that garden $(1805,1808)$, and was the director of the St. Petersburg botanical garden (1823-1850). Stanislaw Boniface Jundzill (1761-1847), a Polish-Lithuanian natural historian and botanist, was professor at the University of Vilnius and also worked as the director of the Vilnius botanical garden. Hungarian botanist Pál Kitaibel (1757-1817), who moved to Pest in 1784 to become professor at the university there (today's Eötvös Loránd University in Budapest). Heinrich Adolf Schrader (1767-1836), a German physician and botanist who became director of the Gottingen botanical garden in 1794 and was appointed professor in 1803. Curt (Kurt) Sprengel (1766-1833), a German botanist and physician who became professor of medicine at the University of Halle in 1789. Botanist Carl Peter Thunberg (1743-1828), who graduated from the University of Uppsala in 1767 and was the student of Carl von Linné; since 1781 he was professor of medicine and the philosophy of nature at the University of Uppsala. He studied the flora of South Africa, Japan, and Southeast Asia. Carl Ludwig Willdenow (1765-1812) was a botanist, a pharmacist, and a taxonomist, one of the founders of phytogeography, also Alexander von Humboldt's teacher, and director of the Berlin botanical garden from 1801 until his death.

Special emphasis should be placed on one contributor of plant specimens from the Kharkiv area in Ukraine-the little-known French researcher Gislain Francois de la Vigne (Gislenius Franciscus Delavigne 1767-1826). He left France in 1792, studied from 18 November 1794 to 30 September 1799 at the University of 
Erlangen, and defended his doctoral dissertation entitled De Gratiola officinali Linn. eiusque usu praecipue in morbis cutaneis. Disserdatiu inauguralis quam annuente gradioso medicorum ordine in regia Friderico Alexandrina pro Doctoris medicinae gradu legitime obdinendo publico examini submittit austor Gislenus Franciscus de la Vigne ambianus in 1799 (Erlangae, C. C. Th. Kunstmanni, 1799). In 1803, he became the first faculty member in botany at the Kharkiv University, as well as the director of the university's botanical garden. (Petrenko, 2017, pp. 144-154) Since 1799, he was a member of the Regensburg Botanical Society (Regensburgische Botanische Gesellschaft) (Ilg, 1984, p. 38; Sander \& Meikar, 2009, p. 84).

Plant specimens were also contributed from Würzburg's botanical garden by Andreas Roman Wolff (who worked there in 1798-1834), the teacher Johann Weinmann, gardener of the University of Tartu Botanical Garden. Wolff was hardworking, very knowledgeable, and committed to the establishment of the Botanical Garden's collection, where he applied Linnés system. It is thought that Wolff was a dignified teacher for Weinmann in every way (Weinmann, 1810, p. ix; Vogg, 2008; Sander \& Meikar, 2009, pp. 75-76). In the years 1803-1805 and 18091810, small and large sums were paid for seeds and plants to Ludwig Marseille, a gardening entrepreneur from St. Petersburg. Plant material was also obtained from two notable manors near Tartu. From Johann Gottlieb Münnich, owner of the Luunja (Lunia) manor, flower bulbs were purchased in 1803, and plants were obtained from the garden of Reinhold Wilhelm von Liphart's Raadi (Ratshof) Manor gardens, as well from several private gardens in Tartu. In 1804, seeds or plants were received from the gardener Bueck, who had gone to St. Petersburg; in 1804-1809, payments were made to the Tähtvere gardener Christian Oberleitner for local trees, bushes and green plants. In 1808, plants were purchased from the Tallinn gardening company of Georg Haetge (Sander \& Meikar, 2009, pp. 75, 84). Georg Haetke's nursery in Tallinn was one of the most noteworthy. Two gardeners, the Haetge (Hätke) brothers, published writings concerning the availability of plants already at end of the 18th century, and Georg Haetke also traded young plants to Finland (Nummi, 2000, pp. 191-195).

The director of the Library of the University of Tartu Karl Morgenstern stayed in Paris from the end of January to the middle of June 1809. When he learned that the administration of the French Imperial Botanical Garden loved to share their copious supply of seeds with other scientific institutions abroad, Morgenstern wrote in a letter sent to Georges Cuvier, a natural scientist and an old friend of Parrot, that "considering that such a generous stance was lauded everywhere back then, might the University of Dorpat in Russia also be eligible?" He wrote that 
he had a request to relay on behalf of his colleague, the natural history professor Gottfried Albrecht Germann. And Mr. Kummer, the Leipzig bookseller, would consent to convey the seeds. Morgenstern thought that although the seeds might already have been distributed for that year one might hope to obtain them next year, and in that case he could pass the message on to the director of Dorpat's botanical garden Mr. Germann, who could then write to Paris himself and specify what was needed and by what routes the seeds would most expediently reach their destination (Tohvri, 2019, pp. 894-895). Indeed, the well-known Leipzig bookseller Paul Gotthilf Kummer had ties with Tartu, being married to the sister of Ludwig Emil Chicorius, professor of anatomy at the University of Tartu. It is not known whether and to what an extent seeds were sent from the French Imperial Botanical Garden to the University of Tartu Botanical Garden, but it cannot be ruled out altogether.

\section{The development of plant diversity in the Vanemuise Street garden}

When Weinmann (1810, p. xiii) began working at the botanical gardens in 1805, he found there to be about 600 species. However, Germann's Latin plant catalogues from 1804 and 1805 contain different numbers. The 1804 catalogue contains 1,121 taxons from 426 genera in alphabetical order. The 1805 catalogue, analogous to the previous one, contains 1,604 numbered taxons: 1,018 taxons from 463 genera and 46 cases (nos. 335-337, 1003-1028, and 1031-1047) in which the plant is named according to genus or its name is missing altogether. For example, for carnations, 45 names are listed. Thus, no great changes were made in these two years; there were slightly fewer plants in 1805 (1,109 taxons) than in the previous year (1,121 taxons) (EAA, 1804c, EAA.2100.12.25; Sander, Meikar, 2009, pp. 79-80).

In 1807, Germann completed the catalogue of plants at the garden's original location. It was probably based on the state of affairs in the summer of 1807; after all, as it was a matter of pride at the time that the work of professors be published quickly. With regard to the text of the catalogue, Germann wrote:

Our university has only existed for five years, and it has had the botanical gardens for less than four years; At this early stage, do I really dare to present a catalogue of the plants being cultivated there? I admit that I would have 
preferred to wait a bit, but I was hastened by several matters. The main reason, which alone would suffice, is that many people claim the botanical gardens contain almost nothing, and that it is not worth the effort even to look at the plants there are, as most of them are ordinary. Indeed, there are many native plants in the following catalogue, 357 species in all. It is also true that many of the plants in our collection are well known and frequently seen throughout Europe; others are frequently found here in the north, but rare in countries further south. A flower-lover or a pseudo-botanist who only wants to know what a plant will cost him and would have to undertake long journeys to see the specimens would not bother to cultivate all of these plants, nor observe them more closely: quotidiana vilescunt (familiarity breeds contempt). But botanical gardens must include and display such plants. The flora of the land must be represented as completely as possible. It is understandable that a large number of plants, primarily Cryptogamia, cannot be easily placed in such a collection. It is by studying native plants that one becomes a true botanist. I agree with Linné and our unforgettable Fischer [Jakob Benjamin Fischer, 1731-1793, natural scientist living in Riga, a student of Carl von Linné, who published an overview of vascular plants in the Baltic provinces]: turpe est in patria vivere, et patriam ignorare [it is a discgrace to live in one's native land without knowledge of it]. (Germann, 1807a, pp. ii-iv)

Germann adds:

Had I wished, I could have substantially expanded the botanical gardens' catalogue of plants; however, the several hundred seeds that we have already planted, many of which have sprouted and have a good outlook for growth, have not been entered because I cannot be sure of the outcome; not all of them may sprout; neither can one be certain that the development of some (even large) plants might not be halted, resulting in their destruction. Among the latter are some unusual plants from England. Many plants that we previously had are now missing because due to two consecutive poor summers and an early autumn, many summer plants did not bear seeds. We have been able to re-acquire some of them but have yet to receive them all. It should be understandable to all that the task of continually furnishing a garden in the far north with a large quantity of plants from different parts of the world involves difficulties. How thoroughly we must care here for plants that require no care in central or southern Germany: they are simply planted in the ground with no worries about their further growth. 
How many trees, bushes, and perennials there are that grow everywhere in Germany, but do not flourish here, and must be carefully cultivated in containers and pots. Therefore, our greenhouses are much more populated than those in Germany, where it is much warmer. Such and other matters increase our expenditures, even though here wood for heating is not nearly as costly as in other European countries. In addition, it is not easy to find good workers, including day workers. What is to be done with Estonian peasants? How often plants perish because of their laziness, lack of knowledge, lack of motivation or complete inability to even slightly exercise their brains! (Germann, 1807a, pp. iv-x)

Germann's (1807a) catalogue of garden plants is composed of the Latin names of plant genera in alphabetical order; numbers are assigned both to genera and species. Following the numbered name is the author's name, life-form, and the plant's natural area of occurrence (habitat). Among life-forms, distinctions are made between annuals (Sommergewachs oder einjährig), biennials ( $\hat{\jmath}^{\lambda}$ zweyjährig) and perennials (pereinnirend oder Staudengewächs), trees and bushes (Baum und Strauch). Altogether there were 2,367 taxons (species and smaller categories) from 669 genera; a few of these are marked only according to genera or have been left unmarked. Of the 2,367 taxons, there were 536 woody plants, 866 perennials, 702 annuals, and 129 biennials; the life-form of the remaining 134 was left unmarked. On the basis of the plant names one can see that the catalogue differentiates between species that occur in nature (marked with $\mathrm{a}+$ ) from those that live outdoors in the garden $(*)$, meaning plants that can survive the cold; however, the catalogue does not provide explanations for these symbols. A list of the authors who named the species is given at the end of the catalogue. There are some mistakes with regard to life-forms and natural plants. There were 357 native plants (this must mean in reference to the governorates of Estonia and Livonia), while frost-resistant plants growing outdoors constituted a mere $242(10.2 \%)$ (Sander \& Meikar, 2009 , p. 80). There is some confusion here: according to the former gardener Jaan Tänavaots (1969-1996), Germann's catalogue was a list of the plants in the gardens of the Pistohlkors family or Jacob Johann Seebach. Even so, such a large number of previously growing plants is a bit dubious, although it cannot be ruled out. Indeed, Otto Friedrich von Pistohlkors, the owner of the Rutikvere Manor at that time, was famous for his large ornamental garden and his interest in cultivating plants; his younger brother, Woldemar Conrad von Pistohlkors (1755-1801) probably shared these interests. He was the owner of the plot of land where the botanical gardens were later located, and the plants may indeed have come from his brother's estate. 
In 1807, in addition to plants of European, Eurasian, and Siberian origin, the garden contained a large number of plants from Africa, from the Cape (several, for example, 12 species of Stapelia $s p$ ) to North Africa (including Egypt); a number of plants were from South and North America, Southeast and East Asia (India, China, Japan, the Java island, etc.) and the tropics. A specimen of Acaena anserinifolia (J. R. Forst. et G. Forst.) Druce (A. Sanquisorbae V. in Germann's catalogue) that was able to survive under deep winter snow, was from New Zealand. Detailed comments are provided for many species of plants. For example, regarding Erica baccans L., listed in David Hieronymus Grindel's (1803, p. 339) overview of vegetation, Germann (1807, p. 57) thinks Grindel is wrong, and that the correct name is Empetrum nigrum L. At present the natural occurrence of this plant is unproven, and it is rare to find it in cultures (Kukk, 1999, p. 167). Ligularia sibirica (L.) Cass. (Cineraria sibirica L.) was found by Jakob Ludwig Kagel, a student who attended Germann's lectures (in 18061809), and who later became a pharmacist. Kagel found the plant in 1806 at the Annenhof Manor near Tartu (Germann, 1807a, p. 40; Hasselblatt \& Otto, 1889, p. 17). Also, Fragaria viridis Weston (F. collina Ehrh.) which grows in many places in Europe could frequently be found in Livonia and on Tartu's Toome Hill (Germann, 1807a, p. 61).

Many frost-resistant foreign trees and bushes that grow outdoors today could be found in the botanical gardens. Among conifers, Pinus Cembra L. and Pinus Larix L., native to Southern Europe, the Alps and Siberia are marked as frostresistant; in the case of Pinus Larix L. Northern Europe has been added as a site of occurrence. Therefore, it is not exactly known which species were growing at the time in the Botanical Gardens, whether it was P. cembra L., P. sibirica Du Tour, Larix decidua Mill., or L. sibirica Ledeb. (sensu lato). Both species of larches must have grown there. We know that the frost resistance of $L$. sibirica Ledeb. is not mentioned with regard to Juniperus thurifera L., J. virginiana L. and Thuja occidentalis L.; it is assumed that they were kept in greenhouses.

Among the frost-resistant species of deciduous trees and bushes that grow outdoors are Acer pseudoplatanus L., A. tataricum L. and Aesculus hippocastanum L. About the latter it is commented that these trees, planted by Peter I near Riga, continue to grow well there, whereas here the young trees freeze. These are followed in the list by Berberis sibirica Pall. (Altaisches Gebirge, incapable of growing outdoors), Buxus sempervirens L., Cornus alba L., C. mas L. and Laburnum anagyroides Medik. (Germann's term was Cytisus Laburnum L.), the latter with the comment that it did not grow very tall outdoors and usually 
froze each year. For Juglans nigra L. there is a lengthy explanation where we learn that many of these trees were growing in Count Sievers' Bauni estate in Northern Latvia; Lonicera caprifolium L., L. sempervirens L. and L. tatarica L.; Lycium europaeum L., Philadelphus coronarius L. and Populus balsamifera L. About the latter, Germann wrote: "Populus balsamifera L., Sibirien. For some years, enthusiastic efforts have been made to plant these rapidly growing trees. Here and there by the highways one can now find avenues lined with poplars" (Germann 1807a, p. 107). There is a misconception here-P. balsamifera L does not grow in Siberia, but rather in the part of Alaska that belonged to Russia; if it indeed originated in Siberia, we could be dealing with another species. Indeed, P. balsamifera was also listed by Wilhelm Christian Friebe (1805, p. 330). Next to this entry, Germann's catalogue no. 1737 refers to a nameless poplar (Germann, 1807a, p. 107). Also mentioned are Ptelea trifoliata L., Rhus radicans $\mathrm{L}$. and $R$. toxicodendron L.; species widely found in gardens, including Caragana arborescens Lam. (Robinia caragana L.), Rosa $\times$ alba L., $R$. carolina $\mathrm{L}$. ja $R . \times$ centifolia L. and the latter's subspecies 'Muscosa' $(R$. muscosa Ait.) as well as $R$. gallica L., introduced as Rubus arcticus L.; about the latter we learn that it grew well in the garden of the Dikli (Dickeln) Manor in present-day northern Latvia, which belonged to von Tiesenhausen since 1786 (Germann, 1807a, pp. 113-114). This is the first report of the growth of this species in culture.

The botanical gardens included the following plants which grew outdoors and were frost-resistant: Rubus odoratus L., Sambucus nigra L. 'Laciniata', S. racemosa L., Sedum populifolium Pall., Physocarpus opulifolius (L.) Maxim.(Spiraea opulifolia L.), Sorbaria sorbifolia (L.) A. Braun (Spiraea sorbifolia L.), Spiraea chamaedryfolia L., S. crenata Pall., S. hypericifolia L., S. salicifolia L., while it is not known whether S. alpina Pall. and Staphylea trifolia L. are frost-resistant. Also growing outdoors were the following species: Syringa $\times$ persica L: and its cultivar 'Laciniata', S. $\times$ laciniata Mill. (S. persica $\beta$ laciniata), S. vulgaris L. and its double-flowered form $f$. pleno. We learn that Syringa $\times$ laciniata is not a rarity in gardens ("Erst seit wenigen Jahren in Gärten nicht selten"), but it can only survive the winter if it is covered. Viburnum lantana L., Vinca minor L. and its cultivar, 'Variegata' were also found outdoors. Erroneously listed among naturallyoccurring plants were Acer campestre L., which occurs infrequently, Hippophae rhamnoides L. (found by Fischer near Riga) and Ligustrum vulgare L. Species allegedly growing in greenhouses included: Cercis canadensis L., C. siliquastrum L., Clematis florida Thunb. and C. viticella L., Cornus sericea L., Cytisophyllum sessilifolium (L.) O. Lang (Cytisus sessilifolius L.), Cytisus nigricans L., Daphne laureola L. and D. pontica L., Erica carnea L. (E. herbacea L.) and E. multiflora L., 
Carya alba (L.) Nutt. ex Elliott (Juglans alba L.), Castanea sativa Mill. (Fagus Castanea L.), Fraxinus pennsylvanica Marshall var. pennsylvanica (F. pubescens Lam. also F. nigra Du Roi); thus it is unclear which of these species were actually found; Genista tinctoria L. (Genista sibirica L.), Hedera helix L. 'Variegata', Iberis sempervirens L. and I. saxatilis L., Ilex aquifolium L., Juglans regia L., Koelreuteria paniculata Laxm. (K. paniculata Ait.), Lycium barbarum L. and L. ruthenicum Murray, Myrica cerifera L., Rhododendron ponticum L. and R. viscosum (L.) Torr. (Azalea viscosa L.), Cotinus coggygria Scop. (Rhus cotinus L.), Caragana frutex (L.) K. Koch (Robinia frutescens Pall.), Robinia pseudoacacia L. (with the separate remark that it does not grow outdoors in this region); Rosa $\times$ centifolia var. parvifolia (Ehrh.) Rehder (R. parvifolia Ehrh.), R. gallica L. 'Versicolor', Rosa chinensis Jacq. var. semperflorens (Curtis) Koehne ( $R$. semperflorens Curt.) and its cultivar 'Old Blush' ('Old Blush China)' ( $R$. semperflorens pallida) and Ulex europaeus L.

\section{The Botanical Gardens on Lai Street and advances in plant diversity}

Gardener Weinmann described the Rosenkampff garden, which he had received as a gift, as follows:

The place is located inside the city, on its northern side. The garden plot is well protected with a good water supply. There are also some buildings, the uses of which have not yet been determined. A suitable site for putting up a new building was measured out, and the construction work was completed by fall 1807. There was another great obstacle to overcome. Namely, on a large part of the grounds houses had once stood, and the remaining territory had been part of a fortress, which had since been demolished. The previous owner had made some expenditures here, but despite such efforts, all the areas to be used as gardens had to be re-excavated at the depth of 3-4 feet. At first only enough land was cleaned up to transplant the existing outdoor plants, thus liquidating the previous garden. This took place in fall 1808. [...]

The years 1809 and 1810 were mostly spent in furnishing the rooms. Bushes still need to be planted in some places; up till now it has been impossible to procure them, because foreign communication was hampered. The lower part of the garden, only a few fathoms' distance from the Emajógi River, is more or less flooded for a short period each year. However, this area has been 
allotted to the gardener for economic use and that is how it can be utilised. I should also mention that the entire south side of the garden is surrounded by two-and-a half-foot wall; the remaining sides are partly adjoined by houses, partly by a board fence. On the east side the garden's grounds are protected by a hill; on the south and west sides by houses and planted areas (gardens). Though the north side is more open, the hill that runs along the northern border provides good protection for the main part of the garden. Because the location is still too limited for a more elaborate structure, I took to heart the task of connecting utility and pleasure as much as possible, so that both together would form a small but friendly whole. (Weinmann, 1810, pp. xi-xiii)

From this passage we also learn that in 1807 , immediately after the completion of the gratuitous contract, work began to adapt the grounds for use as a botanical garden: plants were transferred there since autumn 1808. This was quite a big task, and it seems possible that the transfer continued into the following year.

In view of the year when Weinmann's overview of the vegetation at the new location was published (1810), we can safely surmise that the new catalogue reflected the state of the gardens at the end of 1810. By that time, the plants had been transferred to their new location over a period of two years, and new ones had been planted. The catalogue presents the plants in alphabetical order according to their Latin names, with some descriptions included, and garden plants are differentiated from the naturally occurring ones that Weinmann collected on his hikes in the Tartu area. A section for Corrigenda et addenda is included at the end of the catalogue. The plants are arranged according to the same growth forms as in Germann's 1807 catalogue, but the 1810 catalogue is much more detailed and extensive. With this work Weinmann demonstrated his high level of competence; it is not known whether he reclassified the plants during the process of transferring them or later on. Reclassification probably applied if there were plants on the list from the old location. However, some confusion remains, since we do not know the size of the plants from the old location, which in turn depended on the proportions of the plants that had been transplanted and those which were grown from seeds. The latter of course, were very small.

Weinmann's list indicates the environment where the plant grows, whether it is warm (Caldarium) or cold (Frigidarium), in the greenhouse or out in the open (Sub. div.). In the latter case, two slash marks indicate those plants that are covered for the winter. Different types of greenhouses have been adopted along the model of buildings at the Linnaean Gardena of Uppsala: 
The orangery was built in 1744 according to a plan drawn by the architect Carl Hårleman; it was divided into three sections named after the divisions in Roman baths. Frigidarium was the coolest. Plants which spent the summer on the gravel ground in front of the orangery were kept in the Frigidarium during the winter. [...] Caldarium was warm and humid. Tropical plants were kept there. Tepidarium was the hot, dry department where succulents and plants from South Africa were grown. (The Linnaean Gardens of Uppsala, 2019)

Thus, it is probable that the two new greenhouses at the University of Tartu Botanical Garden were built according to previous models.

Plants that Weinmann had procured himself were marked with an asterisk. Some descriptions and comments regarding plant species are also included (Weinmann, 1810 , pp. 1-170). According to research literature, there were 4,360 species in the garden at the time in Weinmann's catalogue, 509 of which were naturally occurring (Siilivask, 1982, p. 186). According to further specification of data, the 1810 catalogue contained, based on the nomenclature of the time, 4,586 entries for plants from 968 genera, of which there are only two whose growth environment has not been indicated. Out of 4,583 taxons, 742 grew in the Caldarium greenhouse, 1,508 in the Frigidarium greenhouse and 2,358 outdoors (Sub. div.), a total of 4,608 plants, 24 of which grew in two environments, the Frigidarium and outdoors. Of the 4,586 taxons, 496 were naturally occurring plants. However, as knowledge of the flora of the provinces of Estonia and Livonia was incomplete at that time and the dissemination area of foreign species was unclear, Weinmann had counted some foreign species among the local naturally occurring plants, and thus mistakes occurred in classification. Though studies had already been published about the cold-resistance of plants in the garden of the Alūksne (Marienburg) Manor (Schmidt, 1800, pp. 2-25; Buek, 1804, pp. 2-14) somewhat south of Tartu, the ability of many plants to grow outdoors had not been clarified. The number of plants able to grow outdoors is therefore an indicator of the quality of gardening in the region, showing the knowledge of gardeners about our climate and the cold-resistance of plants. Compared to the plants that Germann had entered in his catalogue from the previous location, more plants had now been acquired, particularly from the genera Allium, Aloe, Artemisia, Aster, Cactus, Campanula, Centaurea, Dianthus, Euphorbia, and Hedysarum.

In addition to the cold-resistant plants from the previous location, many new plants grew on the new grounds, both outdoors and in greenhouses. Outdoor 
conifers included Abies balsamea (L.) Mill. (W.-1 Pinus balsamea L.), of course Larix sp. (Pinus larix L.), Larix laricina (Du Roi) K. Koch (in Weinmann's catalogue Pinus microcarpa Lamp.) and Pinus strobus L; in the cold greenhouse one could find Chamaecyparis thyoides (L.) Brittom, Sterns \& Poggenb. (Cupressus thyoides Wag.), Picea glauca (Moench) Voss (Pinus canadensis Ait.), apparently Pinus cembra L. (P. Cembra L.), but one could not rule out P. sibirica Du Tour, Platucladus orientalis (L.) Franco (Thuja orientalis L.) and Thuja occidentalis L. Deciduous trees, bushes and lianas found outdoors were Parthenocissus quinquefolia (L.) Planch. (W.-1 Cissus hederacea Pers. and Hedera quinguefolia L.), Cornus florida L., C. sanguinea L. (C. sanguinea l'Her.), C. sericea L. (C. sericea l'Her.), Crataegus laevigata (Poir.) DC (C. oxyacantha L.), Juglans nigra L., Genista tinctoria L., Populus deltoides Bartram \& Marshall (P. angulata Ait.), Populus $\times$ jackii Sarg. 'Gileadensis' (P. candicans Ait.) and P. nigra L. 'Italica' (P. dilatata Wild.), Malus baccata (L.) Borkh. (Pyrus baccata Pall.), Ribes diacanthum Pall., $R$. nigrum L. 'Varigeta' $(R$. nigrum $\beta$ foliis variegatis), Rubus fruticosus L. (also found in 1807 in the previous garden), Salix alba L. and its variant var. vitellina (L.) Stokes (S. vitellinna Hoff.), Spiraea alba Du Roi (S. salicifolia $\gamma$ paniculata Ait.), S. trilobata L., Syringa $\times$ chinensis Willd., S. vulgaris L. f. alba. Outdoor plants that needed to be covered in the winter were Acer tataricum L., Caragana frutescens L., Chionanthus virginicus L., Crataegus crus-galli L. (C. crus-galli Ait.), C. monogyna Jacq. 'Plena' (C. monogyna $\delta$ flore pleno), Carya alba (L.) Nutt. ex Elliott (Juglans alba L.); also requiring cover in the winter were Cytisophyllum sessilifolium (L.) O. Lang (Cytisus sessilifolius L.), Euonymus latifolius (L.) Mill., Halimodendron halodendron (Pall.) Voss (Robinia halodendron Pall.), Hippocrepis emerus (L.) Lassen (Coronilla emerus L.) and Laburnum anagyroides Medik. (Cytisus Laburnum L.). Plants that did not need coverage in the winter were Lonicera periclymenum L., Periploca graeca L., Populus alba L. and Prunus armeniaca L. There were many briers (Rosa spp.) outdoors and in the cold greenhouse, 21 (14 outdoors, 2 that did not need covering, 1 native and 1 foreign species): for example, growing outdoors were Rosa $\times$ alba L. 'Plena' ( $\beta$ flore pleno), R. carolina L., $R . \times$ centifolia $\mathrm{L} ., R . \times$ damascena Mill. ( $R$. Damascena Ait.), $R$. gallica L. 'Versicolor' ( $\beta$ versicolor Mill.), $R$. moschata Herrm., $R$. rubiginosa L., $R$. spinossima L. ( $R$. pimpinellifolia $\mathrm{L}$. and $R$. spinossima $\mathrm{L}$.) and $R$. virginiana Herrm. (R. lucida Ehrh.), Rubus hirtus Waldst. \& Kit. (R. hirtus Kit.), Sambucus nigra L. 'Laciniata' and 'Variegata' ( $\beta$ laciniata Mill. and $\gamma$ foliis variegatis), Staphylea pinnata L. and Viburnum opulus L. 'Roseum' ( $\beta$ roseum Bauh.). Outdoor briers requiring coverage for the winter were Rhus toxicodendron $\mathrm{L}$. ( $R$. toxicodendron Wang.) and $R$. radicans $\mathrm{L}$.; not in need of winter coverage were Spiaea alba Du Roi (S. salicifolia $\gamma$ paniculata Ait.), S. chamaedryfolia L., S. crenata Mill., S. hypericifolia L., S. salicifolia L. (S. salififolia Ait.), and S. triloba L. 
Growing in the cold greenhouse (Frigidarium) were Juniperus virginiana L., Amelanchier canadensis (L.) Medik. (Pyrus ovalis Willd.), Argyrolobium zanonii (Turra) P. W. Ball (Cytisus argenteus L.), Berberis sibirica Pall., Caragana spinosa (L.) DC (Robinia spinosa L.) and C. jubata (Pall.) Poir. (Robinia jubata Pall.), Catalpa bignonioides Walter (Bignonia catalpa L.), Clematis viorna L. and $C$. virginiana $\mathrm{L}$., Colutea arborescens $\mathrm{L}$. and $C$. orientalis Mill. (C. cruenta Ait.), Chamaecytisus austriacus (L.) Link (Cytisus austriacus L.), C. ratisbonensis (Schaeff.) Rottm. (Cytisus biflorus Ait.), C. supinus (L.) Link (Cytisus supinus Jaq.) and C. hirsutus (L.) Link, (Cytisus hirsutus L.), Crataegus pentagyna Waldst. \& Kit. Ex Willd., Gleditsia triacanthos L., and Lembotropis nigricans (L.) Griseb. (Cytisus nigricans L.).

There were foreign species of heather, for example Erica multiflora L., E. scoparia L. and E. tetralix L.; also listed were Hydrangea arborescens L. and H. radiata Walter, Rhododendron maximum L. and R. ponticum L., Robinia pseudoacacia L., R. viscosa Vent., Sibiraea laevigata (L.) Maxim. (Spiraea laevigata L.) and Vinca major L.

In addition to the 1810 catalogue, Carl Friedrich Ledebour, who was appointed the new professor of botany the following year, published a supplementary list of plants in November 1811. Here the names of plants are given in Latin without authors' names. The list contains 507 taxons from 242 genera. Added to the list of woody plants were Gleditsia macracantha Desf., Philadelphus coronarius L. 'Nanus' from China and P. inodorus from North America. Some names from Weinmann's list have also been included. In some databases, this work has been regarded as the first introduction of the seeds available from the botanical gardens.

\section{Conclusion}

The developments in the Russian society in the second half of the 18th century highlighted, among other things, the general attitudes towards education and science. Russia's backwardness in this regard was acknowledged. Sole reliance on the youth who studied in foreign universities was considered insufficient and regressive, at times even dangerous for the underdeveloped society. The main driving force for the attitudes emerged in the region encompassing the provinces of Estonia, Livonia, and Courland and the new capital of Russia, St. Petersburg, with its immediate surroundings. A major part in this was played, of course, by the Baltic German elite in the aforementioned provinces, who had become an 
influential group with close ties with persons at the helm of the state.

The Enlightenment ideas of the final decades of the 18th century, which were not particularly favoured, and the French Revolution beginning in 1789, which shook the society, were among the reasons for the reopening of the University of Tartu. It is believed that the determining factor was the fear of Paul I of the potential infiltration of the ideas of the French Revolution through the students studying in Europe. For that reason, the subjects of the Russian Empire were even banned from studying abroad in the first half of 1798. All this ultimately led, in 1802, to the reopening of the University of Tartu, which became a mediator of European culture to the Russian Empire through both its professors and students. Among the former, the principal players were persons who had been born in the provinces and had received their education in Western universities and also those who had arrived from the Western Europe and had come here in the capacity of tutors or intellectuals. All these factors facilitated the rise of the University of Tartu to international renown as a scientific institution.

The foundation for all the aforesaid, however, was laid by those who became lecturers at the newly reopened University. The University needed individuals with teaching skills, research talents or organising capacities (Siilivask, 1982, p. 54). Finding such people or the ability to discern the said qualities in them was another matter. Representatives of various vocations who had been educated in different universities formed the teaching staff. Among the criteria for selection were a doctoral degree and personality traits, to some degree also personal connections and previous career. Based on the list of chairs stated in the 1803 Statutes, the University was to employ 41 lecturers; in reality, some of the seats remained unoccupied. Among the professors at the "embryonic" University, the most preeminent ones were Georges Frédéric (Georg Friedrich) Parrot from Montbéliard (Mömpelgard), professor ordinarius of theoretical and experimental physics; Martin Ernst Styx, professor of pharmacology, who was born in Riga and practised medicine in several locations; Daniel Georg Balk from Königsberg (Kaliningrad), who was the professor of pathology and physiology and worked as a medical practitioner; Gottlob Benjamin Jäsche from Wartenburg (Syców), professor of philosophy, who had been a private docent at the University of Königsberg (1799-1802) and later worked as a tutor; Georg Friedrich Pöschmann from Naumburg, professor of general history, statistics and geography; Johan Karl Simon Morgenstern from Magdeburg, professor of classical philology and art history and the director of the University's library; Gottfried Albrecht Germann, and others (Siilivask, 1982, pp. 54-55), later also Johann Wilhelm Krause for its activities as the University's 
architect and teacher. In scientific literature, particular focus has been on three of them-Parrot, Morgenstern, and Krause—and their life and work.

Prior to them, Gottfried Albrecht Germann, along with several others, had been the most renowned and active figure, considering his studies and activities at the universities of Jena, Würzburg, Berlin and Kiel, subsequent medical practice and previous interests.

In sum, Germann's achievements at the University of Tartu were fairly substantial for his short life despite the fragile health, which led to his premature death just before the age of 36 .

His most important contributions were his activities as a teacher and work at the development of the University of Tartu, the founding of the Natural Cabinet and the Botanical Garden, as well as his research activities. He was one of the founders of subsequent developments in the relations of humans and the environment (climate), which were touched upon in his doctoral dissertation. Germann also introduced a qualitative change in the research on botany as a science, contributed to the study of the flora of the provinces of Estonia and Livonia, and organised major expeditions not only to the territories of the present-day republics of Estonia and Latvia but also to the Seto region, and further north to the Finnish areas of Russia. Furthermore, the University's Botanical Garden evolved into an important centre of information, sharing knowledge on new and so far undescribed plants.

In March 1808, Germann attended his last Communion at Jaani [St. John's] Church, and died on 28 November 1809, apparently of tuberculosis. Germann's funeral ceremony took place in the University's Assembly Hall. From there, students carried his coffin to the Raadi cemetery (Krause, 1902, pp. 88-89; Sander et al., 2009, p. 545). He was buried in the Vana-Jaani segment of the cemetery, Section XV under no. 6. Germann had no offspring. His wife Juliane lived in Tartu until at least 1812, managed her husband's legacy and attended the baptism of Elisabeth, the daughter of Paul and Catharine (born Günzel) von Sievers (Sander et al., 2009, p. 545).

Gottfried Albrecht Germann had a most remarkable collection of books on natural history and botany, including some very expensive and rare volumes. Most of them were sold by his widow Juliane due to financial pressure while a part was presented to the University. Germann's collection of insects actually belonged to her father-in-law and since he was very interested in selling it, the 
70-year-old man would obtain 1,000 roubles for that. The exact fate of the books and collections is unknown or unexplained (Germann, 1811).

Juliane died on 5 October 1839 at Bauni and was apparently buried in the local manorial graveyard. Her grave marker has not survived (Sander et al., 2009, p. 545).

To be a trailblazer is always difficult and complicated, for one is eclipsed by the competence and capability of those who follow. Moreover, as each new generation starts off on its own trail, finding new ones is not so easy.

\section{Acknowledgments}

The author's special thanks go to the science historian Toivo Meikar from Tartu, who has contributed to the preparation of earlier articles on this topic. In this case, he did not consider his co-authorship necessary. The author also thanks ornithologist Olav Renno, who clarified the significance and substance of the seagull study by Gottfried Albrecht Germann. I also thank Arvo Tering, a research historian from Tartu, for sending a copy of Germann's doctoral thesis and for the informative conversation; dendrochronologist Alar Läänelaid for sending data from Tartu about the age of trees of the Bauñi Manor; Dāvis Pumpuriņ̌̌ and Ingrïda Zìrinad from the Jelgava Museum for new information on Germann and Johann Hermann Walter; science historian Wolfgang Ilgi from Regenburg in Germany; and professional translator Kadri-Ülle Masing from Tallinn for reading and translating Juliana Germann's letters and other material.

\section{References}

Aarma, L. (2007), Póhja-Eesti vaimulike lühielulood 1525-1885 [Pastors of North Estonia short biographies 1525-1885], Póltsamaa (Harjumaa): Vali Press.

Anonymus (1804), 'Dorpat. Der hiesige Prof. der Naturgeschich te, Hr. Hofr. Germany hat bereits im vo rigen Iahre eine Reise durch Esthländ... Botanische Notizen,' Flora oder Botanische Zeitung, no. 23, pp. 367-368.

Baltinšs, J. (2006), 'Gutshöfe der Grafen Sievers: Kultureller und wissenschaftlicher Mittelpunkt in Livland,' in H. Wittram (ed.) Baltische Gutshofe Leben-KulturWirtschaft, Lüneburg: Verlag Carl-Schirren-Gesellschaft, pp. 107-136. 
Batsch, A. J. G. C. (1793), Nachricht von der Gründung einer naturforschenden Gesellschaft zu Jena am 14 ten July 1793 nebstn dabey gehaltnen Reden, den Statuten der Geschellschaft und dem Verzeichniss ihrer Mitglieder, Jena: Commission der Cuinoissen Buchhandlung.

Bergmann, E. v. (1896), Von unseren Vorfahren. Eine Familienchronik, Berlin: L. Schumacher.

Blum, K. L. (1858), Ein russischer Staatsmann. Des Grafen Jakob Johann Sievers Denkfürdigkeiten zur Geschiche Rußland, Vierter Band; Leipzig und Heidelberg: C. F. Winte'sche Verlagshandlung.

Brennsohn, I. (1905), Die Aerzte Livlands von den ältesten Zeiten bis zur Gegenwart. Ein biographisches Lexikon nebst einer historischen Einleitung über das Medizinalwesens Livlands, Riga: Verlag von E. Bruhns.

Buek [Bueck, P.] (1804), Erstes Supplement zum Marienburgischen Pflanzen-Verzeichnisse, wovon Doubletten gegen Tausch oder ftir Bezahlung wie auch, mehrere seltene schöne Saamen zu haben sind, Dorpat: Mich. Gerh. Grenzius.

Chalmers, L. (1788), Nachrichten über die Witterung und Krankheiten in Südcarolina. Nebst John Linings Tabelle über die Aus- und Absonderungen des Körpers im dortigen Klima, Aus dem Engl, Erster Band, Stendal: Franz und Grosse.

Chladni, E. F. Fr. (1794), Über den Ursprung der von Pallas gefundenen und anderer ihr ähnlicher Eisenmassen und über einige damit in Verbindung stehende Naturerscheinungen, Riga: Johann Friedrich Hartknoch.

Chulkova, N. M., ed. (1914), 'Geydeke (Heidecke),' in Russkiy biograficheskiy slovar, tom 4: Gaag-Gerbel, Moskva: G. Lissnera \& D. Sovko, pp. 337-339.

EAA (1803-1814), Kontrakte, Protokollextrakte und Briefwechsel mit den Beamten des botanischen Gartens, dem Kurator des Dorpater Lehrbezirks u.a. über die Errichtung und Versetzung des Gartens, den Verkauf des alten Gartens u.a., EAA.402.5.52, State History Archives, Tartu.

EAA (1804a), Akte betreffend die Gerichtliche Einweisung des dem Professor Carl Morgenstern vom Konseil bewilligten Domplatzes, EAA.402.8.483, State History Archives, Tartu.

EAA (1804b), Inventarium der botanischen Gartens der kaiserlichen Universität zu Dorpat. Geführt von der Direktor der Gartens, EAA.2100.2.25, State History Archives, Tartu.

EAA (1804c), Taimede alfabeetiline nimestik, EAA.2100.12.25, State History Archives, Tartu.

EAA (1805-1828), Veinmann, Johann Anton, EAA.402.3.276, State History Archives, Tartu.

EAA (1806), Protokollextrakt und Antrag des Professors Germann betreffend die Herausgabe eines russischen Gelehrtenkexikons von Probst Heideke in Moskau, EAA.402.4.186., State History Archives, Tartu. 
The Life and Activities of Professor Gottfried Albrecht Germann, the First Natural History Professor at the University of Tartu

EAA (1848-1903), Protokollextrakte und Briefwechsel mit dem Kurator des Dorpater Lehrbezirks, der Rentkammer u.a. betreffend den vom Professor Morgenstern der Universität geschenkten Domgarten, EAA.402.5.409, 1. 3-4, State History Archives, Tartu.

EAA (1902-1913), Kimmel Gustav Karl, EAA.402.3.770, State History Archives, Tartu.

Ewers, J. P. G., ed. (1827), Die Kaiserliche Universität zu Dorpat. Fünfundzwanzig Jahre nach ihrer Gründung, Dorpat: J. Ch. Schünmann.

Farjon A.; Gardner M. \& Thomas P. (2019), 'Conifer Database (version Jan 2014),' in Y. Roskov et al. (eds.) Species 2000 \& ITIS Catalogue of Life, 2019 Annual Checklist, Leiden: Species 2000: Naturalis. Retrieved from http://www.catalogueoflife.org/ annual-checklist/2019 [accessed 19 Oct 2019]

Finke, L. L. (1792), Versuch einer allgemeinen medicinisch-praktischen Geographie, worin der historischen Theil der einheimischen Völker - und Staaten, Erster Band, Zweyter Band, Leipzig: Weidmannische Buchhandlung.

Finke, L. L. (1795), Versuch einer allgemeinen medizinisch - praktischen Geographie, worin der historischen Theil der einheimischen Völker - und Staaten - Arzeneykunde vorgetragen wird, Dritter Band, Leipzig: Der Weidmannische Buchhandlung.

Germann, J. (1803?), Letter from 10 April 1803? to Karl Morgenstern, Dorpat, University Library collections: Letters to Karl Morgenstern, 05 vol. [37], p. 274. Retrieved from http://dspace.ut.ee/handle/10062/2333?locale-attribute=et [accessed Apr 2019]

Germann, J. (1808), Letter from 11 July 1808 to Karl Morgenstern, Dorpat, University Library collections: Letters to Karl Morgenstern, 06 vol [106], pp. 319-320. Retrieved from http://hdl.handle.net/10062/4026 [accessed Apr 2019]

Germann, J. (1811), Letter from 7 Marchl 1811 to Karl Morgenstern, Dorpat, University Library collections: Letters to Karl Morgenstern, 06 vol. [106], p. 323. Retrieved from http://hdl.handle.net/10062/4026 [accessed May 2019]

Germann, G. A. (?) (1803), Vorschriften für die Studierenden auf der Kaiserlichen Universität zu Dorpat, Dorpat: Michael Gerhard Grenzius.

Germann, G. A. (1804), 'Schreiben über seine botanische Reise nach dem russ. Finland, und über den Botanische Garten zu Dorpat,' Bot. Zeit., vol. 3, no. 21, pp. 328-336; no. 22, pp. 344-348.

Germann, G. A. (1805a), 'Reise durch Estland, vorzüglich botanischen Inhalts, im Sommer 1803 unternommen von dem Herrn Professor Germann in Dorpat,' in D. H. Hoppe (ed.) Neues botanisches Taschenbuch für die Anfänger dieser Wissenschaft und der Apothekerkunst auf das Jahr 1805, Nürnberg \& Altdorf: J. E. Monath und J. F. Rußler, pp. 57-104.

Germann, G. A. (1805b), 'Ueber Pflanzenliebhaberey in Russland,' Flora oder Botanische Zeitung, no. 2, pp. 17-32.

Germann, G. A. (1807a), Verzeichniss der Pflanzen des botanischen Gartens der kaiserlichen Universität zu Dorpat im Jahr 1807, Dorpat: M. G. Grenzius. 
Germann, G. A. (1807b), 'Anderweitige Bekanntmachungen. Ich habe von Sr. Erlaucht, dem Herrn Geheimerath und Ritter, Grafen v. Sievers...,' Beylage zur Dörptschen Zeitung, no. 33, pp. 2-3.

Germann, G. A. (1807c), 'Auerdissiment. Jeder Sammler von Naturprodukte fühlt es bald, wie schwer es ist, eine reichhaltige Sammlung zu erhalten, wenn er allein sich diesem Geschäft unterziehen muß..., Beylage zur Dörptsche Zeitung, no. 102, 22 December, pp. 1-2.

Germann, [G.] [A.] (1808), 'In dem Tagebuche meiner esthnischen Reise...,' Korrespondenz - Nachrichten. Dorpat, Janus oder Russische Papiere. Eine Zeitschrift für das Jahr 1808, Erstes Heft, pp. 143-145.

Germann, G. A. (1809), 'Ueber eine nordische Mevenart', Annalen der Wetterauischen Gesellschaft für die gesammte Naturkunde, I Band, vol. 2, no. 22, pp. 240-248.

Germann, G. A. (2018), 'Reis mööda Eestimaad, eeskätt botaanilise sisuga. Sooritanud härra professor Germann Tartust 1803. aasta suvel' [A journey through Estonia, primarily with a botanical aim. Made by Professor Germann from Tartu in summer 1803], Akadeemia, vol. 30, no. 6, pp. 1013-1041.

Grindel, D. H. (1803), Botanisches Taschenbuch für Liv-, Cur-und Ehstland, Riga: C. J. G. Hartmann.

Hasselblatt, A. \& Otto, G. (1889), Album Academicum der Kaiserlichen Universität Dorpat, Dorpat: C. Mattiesen.

Heidemaa, I. (1972), 'Zooloogiamuuseum 150-aastane,' [...] Eesti Loodus, vol. 13, no. 8, pp. 456-462.

Hein, A. (2007), 'Aed ja aeg. Piirjooni eesti aiakunsti vanemast ajaloost' [Gardens and time. Some aspects of Estonian gardening in early history], in E. Luttsepp (ed.) Eesti pargid, vol. 1, Tallinn: Ministry of the Environment, National Heritage Board \& Varrak, pp. 17-87.

Hein, A. (2009), Koluvere, Tallinn: Hattorpe.

Hein, A. (2010), 'Virtsu ja Puhtu. Pilk minevikku' [Virtsu and Puhtu. A look into the past], in T. Kukk (ed.) Estonia Maritima, vol. 8, Tartu: MTÜ Estonia Maritima, pp. 5-38.

Hein, A. (2016), 'Inglise pargistiili algusaegadest Eestis' [The beginnings of English park style in Estonia], in T. Tammet (ed.) Eesti parkide almanahh, vol. 4, Tallinn: Keskkonnaministeerium, Muinsuskaitseamet, pp. 10-23.

Hellfritzsch, R. (2015), Baltische Wissenschaftler zwischen Deutschland und Russland: David Hieronymus Grindel und Alexander Nicolaus Scherer, Deutsch Baltisches Jahrbuch. Jahrbuch des baltischen Deutschtums, Neue FolgeBand 63, pp. 86-110.

Hollander, B. (1980), Geschichte der Domschule, des späteren Stadtgymnasiums zu Riga, Beiträge zur Baltischen Geschichte, vol. 10, Hannover-Dören: Verlag Harro v. Hirschheydt.

Ilg, W. (1984), Die Regensburgische Botanische Gesellschaft. Ihre Entstehung, Entwicklung und Bedeutung, dargestellt anhand des Gesellschaftsarchivs, Regensburg: Verlag der Gesellschaft. 
The Life and Activities of Professor Gottfried Albrecht Germann, the First Natural History Professor at the University of Tartu

Jochmann, J. L. (1804), Tagebuch der Lappländischen Reise. Retrieved from https://dspace. ut.ee/bitstream/handle/10062/62940/mscr818.pdf? sequence $=1$ \&isAllowed $=y$ [accessed Apr 2019]

Kozhin, M. N. \& Sennikov, A. N. (2016), 'The Russian larch (Larix archangelica, Pinaceae) in the Kola Peninsula,' Memoranda - Societatis pro Fauna et Flora Fennica, no. 92, pp. 79-91.

Krause, J. W. (1902), 'Das erste Jahrzehnt der Ehemaligen Universität Dorpat,' Baltische Monatsschrift, vol. 44, no. 53, pp. 229-250, 330-346, 361-385; vol. 54, pp. 81-103.

Kriisa, A. (2016a), Tartu ülikooli botaanikaaia rajamine ja kujunemine 19. sajandi esimesel poolel [The establishing and development of the Botanical Garden of the University of Tartu in the first half of the 19th century], MA thesis, Institute of History and Archaeology, University of Tartu. Retrieved from http://dspace.ut.ee/ bitstream/handle/10062/52801/Annegret_Kriisa_2016.pdf [accessed Nov 2019]

Kriisa, A. (2016b), 'Botaanikaaed?' [Zusammenfassung. Der Botanische Garten], in A. Ormisson-Lahe (ed.) Johann Wilhelm Krause 1757-1828. Kataloog / Katalog 4, Ülikool Emajóe Ateenas / Die Universität im Embach-Athen, Tartu: Tartu Ülikool, pp. 154-173.

Kukk, I. (2017), 'Item of the month: April 2017,' University of Tartu Natural History Museum. Retrieved from https://www.natmuseum.ut.ee/en/content/item-monthapril-2017 [accessed October 2019]

Läänelaid, A. (2019), E-mails to Heldur Sander, 27 March \& 13 April.

Ledebour, C. F. (1811), Supplementum I. Enumerationis plantarum Horti botanici Dorpatensis... Dabam Dorpati Livonorum d. II/23 Novembris 1811, Dorpat: M. G. Grenzius.

Le Lièvre, A. (2004). 'Nineteenth-century Dorpat and its botanical influence,' Curtis's Botanical Magazine, vol. 14, no. 1, pp. 35-55. https://doi.org/10.1111/j.1467-8748.1997.00062.x

Leng, R. L. G. \& Lenz, Chr. H. Fr. (1807), 'Auf Befehl Seiner Kaiserl. Majestät, des Selbstherrschers aller Reußen ie. ie,' Dörptsche Zeitung, no. 8, 27 Januar, pp. 6-7.

Lenz, W., ed. (1970), Deutschbaltisches biographisches Lexikon 1710-1960, Köln \& Wien: Böhlau Verlag.

Leppik, L. (2016), 'Kus elas Tartu professor?' [Zusammenfassung. Wo lebte der Dorpater (Tartuer) professor], in A. Ormisson-Lahe (ed.) Johann Wilhelm Krause 1757-1828. Kataloog / Katalog 4, Ülikool Emajóe Ateenas / Die Universität im Embach-Athen, Tartu: Tartu Ülikool, pp. 453-482.

Leppik, L.; Laumets, L. \& Lust, K. (2008). Tartu Ülikooli kollektsioonide kaardistamine 2006-2007 (Elektrooniline teavik) [Mapping of the collections of the University of Tartu in 2006-2007]. Retrieved from https://www.academia.edu/26585214/ Tartu_Ülikooli_kollektsioonide_kaardistamine_2006-2007_Elektrooniline_ teavik_Mapping_of_the_collections_of_the_University_of_Tartu_in_2006-2007 [accessed Nov 2019] 
Levitskiy, G. V., ed. (1902), Biograficheskii slovar professorov i prepodavatelei Imperatorskago Iurievskago, byvshego Derptskago, Universiteta za sto let sushchestvovaniia, 1802-1902, vol. 1, Yuriev: Tipografiia K. Mattisena.

Lindeman, E. von (1884), 'Dritter bericht über den Bestand meines Herbariums. Verzeichniss derjeniger Botaniker, welche zu meinem Herbarium beigetragen haben,' Bulletin de la Société des naturalistes de Moscou, t. LX, no. 4, pp. 265-312.

Lipshits, S. I., ed. (1947-1952), Russkie botaniki. Biografichesko-bibliograficheskii slovar, vol. 3, Moskva: Izdatelstvo Moskovskogo obshchestva ispytatelei prirody.

Loewinson-Lessing, F. (1897), Catalogue de la collection de météorites de L'Univérsite Impériale de Ioureiff (Dorpat) (Musée minéralogique). Retrieved from https://dspace. ut.ee/bitstream/handle/10062/3601/catalogue.pdf? sequence = 1 \&isAllowed =y [accessed May 2019]

Loosme, I. \& Rand, M., eds. (1992), Georg Friedrich Parroti ja Karl Morgensterni kirjavahetus 1802-1803 = Briefwechsel zwischen Georg Friedrich Parrot und Karl Morgenstern 1802-1803, Tartu: Tartu Ülikool.

Luts, M. (2002), 'Vaimude veerandtund rüütelkondade kuratooriumiga' [A ghostly quarter-hour with the knighthoods' board of trustees], Ajalooline Ajakiri, vol. 35, no. $1 / 2$ (116/117), pp. 11-32, 309-310.

Maiste, J. (2006), 'English-style garden and Baltic identity,' in L. O. Larsson (ed.) Kunstund Kulturgeschichte im Baltikum. Homburger Gespräche, Kiel: M.C.A. BöcklerMare-Balticum-Stiftung, pp. 131-148. https://doi.org/10.12697/BJAH.2013.6.06

Maiste, J. (2013), 'Kadriorg: the spirit of Baroque and the will of genius. A palace on the edge of the Third Rome,' Baltic Journal of Art History, vol. 6, pp. 153-176.

Maiste, J. \& Ormisson-Lahe, A. (2016), 'Botaanikaaed / Der Botanische Garten. Kataloog 1805-1824', in A. Ormisson-Lahe (ed.) Johann Wilhelm Krause 17571828. Kataloog / Katalog 4, Ülikool Emajöe Ateenas / Die Universität im EmbachAthen, Tartu: Tartu Ülikool, pp. 175-188.

Meyer, B. (1815), Kurze Beschreibung der Vögel Liv- und Esthlands, Nürnberg: Johann Leonhard Schrag. https://doi.org/10.5962/bhl.title.95678

Morgenstern, K. (1808), Letter to Julie Germann, 20. Juli. Dorpat, J. K. Morgenstern's personal archives, F 3, Manuscripts and Rare Books Department.

Nordmann, A. von (1865), 'Christian Steven, der Nestor der Botaniker', Bulletin de la Société impériale des naturalistes de Moscou, vol. 38, no. L, pp. 101-161.

Nummi, A. (2000), 'Ilu- ja viljapuude müük Eesti puukoolidest Soome 1820. ja 1830. aastail' [The sale of ornamental and fruit trees from Estonian nurseries to Finland in the 1820s and 1830s], Dendroloogilised uurimused, vol. 2, pp. 191-196.

Ormisson-Lahe, A. (2011), 'Toomemäe park / Der Park auf dem Domberg. Kataloog (1803-1819),' in A. Ormisson-Lahe (ed.) Johann Wilhelm Krause. 1757-1828. Kataloog / Katalog 3. Linnaehitajana Tartus / Als Stadtbauer in Tartu, Tartu: Tartu Ülikool, pp. 333-366. 
The Life and Activities of Professor Gottfried Albrecht Germann, the First Natural History Professor at the University of Tartu

Pani, T. (2007), 'Reiside kollektsioonidest Tartu ülikooli geoloogiamuuseumis' [An overview of geological collections donated to the UT Museum of Geology by research travellers], Tartu ülikooli ajaloo küsimusi, Uurimisreisid ja muuseumikogud, vol. 36, pp. 126-136.

Pani, T. (2009), E-mail to Heldur Sander, 15 October.

Petrenko, V. V. (2017), 'Vosstanlivaia istoriiu. Poisk materialov o zhizni i deiatelnosti pervogo inostrannogo professora kharkovskoga universiteta, botanika Frantsa Aleksandrovitsa Deliavinia,' in V. V. Petrenko \& D. V. Leontiev (eds.) Kulturna sladzhchina Slobozhamzhchini. Zb. Nauk.-popul. st., Kharkiv: Kursor, no. 1, pp. 144-154. Retrieved from http://dspace.hnpu.edu.ua/handle/123456789/1168 [accessed Oct 2019]

Petukhov, E. V. (1902), Imperatorskii Yurievskii, byvshii Derptskii universitet za sto let ego sushchestvovanii (1802-1902), Istoricheskiy ocherk, vol. 1, Yuriev: Mattisen.

Pūka, T.; Zunde, R. \& Zunde, I. (2010), Latvijas dārznieki no sendienām lìdz 20. gadsimta nogalei [Latvian gardeners from olden times until the end of the 20th century], Rigā: Latvias Universitāte.

Pumpuriņš, D. \& Zīriņa, I. (2019), E-mail to Heldur Sander, 1 April.

Rambach, Fr. (1809), Jacob Johann Graf Sievers. Eine Vorlesung am Geburtschfeste Sr. Majestät des Kaisers, bey Bekanntmachung der Preisaufgaben für die Studierenden der Kaiserl. Universität zu Dorpat im Bibliotheksaale, Dorpat: M. G. Grenzius.

Rand, M. (2015), Ajaloolise kultuurivara jälgedel. Konrad Gessneri taimejoonistused Tartu Ülikooli Raamatukogus [...], Tartu: Tartu Ülikooli Kirjastus.

Recke, J. Fr. \& Napiersky, K. E. (1829), Allgemeines Schriftsteller und Gelehrten-Lexikon der Provinzen Livland, Esthland und Kurland, Zweyter Band: G-K, Mitau: Johann Friedrich Steffenhagen und Sohn.

Recke, J. Fr. \& Napiersky, K. E. (1832), Allgemeines Schriftsteller und Gelehrten-Lexikon der Provinzen Livland, Esthland und Kurland, Vierter Band: S-Z, Mitau: Johann Friedrich Steffenhagen und Sohn.

Sahk, I. (2007), 'Imeasjad ja pildid imeasjadest. Teaduslike uurimisreiside jäljd Tartu ülikooli kunstimuuseumis' [Curiosities and pictures of curiosities. Contribution of scientific explorations in the University of Tartu Art Museum], Tartu ülikooli ajaloo küsimusi, Uurimisreisid ja muuseumikogud, vol. 36, pp. 103-113.

Sander, H. (2010), 'Kaks haruldast käsikirja Tartu ülikooli botaanikaaiast' [Two rare manuscripts from the Botanical Garden of the University of Tartu], in T. Meikar (ed.) Metsaalmanahh 2010, Tartu: Eesti Metsaselts, pp. 90-93.

Sander, H. (2017), 'From Germany through Livonia (Estonia and Latvia) to St. Petersburg: Gardener Johann Peter Bueck's life and horticultural work,' Hoppea, Denkschr. Regensb. Bot. Ges, vol. 78, pp. 45-82.

Sander, H. (2018), 'Gottfried Albrecht Germann ja tema reisid' [Gottfried Albert Germann and his travels], Akadeemia, vol. 30, no. 6, pp. 1041-1054. 
Sander, H. \& Meikar, T. (2009), 'Tartu ülikooli botaanikaaia algaastad ja esimesed taimekogud' [The early years of the Botanical Garden of the University of Tartu and the first plant collections], in T. Tammet (ed.) Eesti parkide almanahh, vol. 2, Tallinn: Keskkonnaministeerium, Muinsuskaitseamet, pp. 72-85.

Sander, H. \& Meikar, T. (2011), 'Botanical garden of the University of Tartu (Dorpat) and the botanical network in the first half of the 19th century,' Baltic Journal of European Studies, vol. 1, no. 1(9), pp. 230-256.

Sander, H.; Meikar, T. \& Laane, M. (2009), 'Tartu ülikooli esimene loodusloo professor Gottfried Albrecht Germann (1773-1809)' [Gottfried Albrecht Germann (17731809), the first professor of natural history of the University of Tartu], Eesti Loodus, vol. 70, no. 10, pp. 46-50.

Sander, H.; Meikar, T. \& Magowska, A. (2014), 'The learned gardeners of the Botanical Garden of the University of Tartu and their activities (1803-1918),'Acta Baltica Historiae et Philosophiae Scientiarum, vol. 2, no. 1, pp. 53-110. https://doi.org/10.11590/abhps.2014.1.04

Schlippenbach, U. von (1818), Erinnerungen von einer Reise nach St. Petersburg im Jahre 1814, Theil II. Briefe aus Dorpat und Riga, Hamburg: Perthes und Besser.

Schmidt, A. (1800), Verzeichniß derjenigen Gewächse, so sich in der Marienburgischen Gartnerey befinden und wovon Doubletten gegen Tausch oder für Bezahlung, wie auch mehrere seltene schöne Saamen zu haben find, Dorpat: M. G. Grenzius.

Seuberlich, E. (1924), 'Stammtafeln Deutsch-baltischer Geschlechter, I. Reiche,' in Verlag Zentralstelle für Deutsche Personen- und Familiengeschichte E. V. in Leipzig. Commissions-Verlag für Lettland, Estland, Finnland, Polen und Rußland, Riga: N. Kymmel.

Siilivask K., ed. (1982), Tartu Ülikooli ajalugu 1798-1918 [History of University of Tartu], vol. 2, Tallinn: Eesti Raamat.

Sobolev, V. S. (2011), 'Dar s neba spavshii... (K istorii meteorita "Pallasova zhelezo")' [A gift from heaven... (On the history of the meteorite "Pallas Iron")], Studies in the History of Biology, vol. 3, no. 3, pp. 68-71. Retrieved from http://shb.nw.ru/wpcontent/uploads/2018/06/elibrary_17279113_10613534.pdf [accessed May 2019]

Sprengel, K. (1795), Handbuch der Pathologie, Erster Theil: Allgemeine Pathologie, Leipzig: Der Schäferischen Buchhandlung.

Stackelberg, O. M. (1930), Genealogisches Handbuch der baltischen Ritterschaften, Theil 1: Estland, Görlitz (Schles.): Sippenforschung und Mappenkunde E. A. Starke.

Stieda, L. (1890), 'Scherer, Alexander Nicolaus,' in Allgemeine Deutsche Biographie, vol. 31, pp. 99-102. Retrieved from https://www.deutsche-biographie.de/ pnd1 17218545.html\#adbcontent [accessed Apr 2019]

Storch, H., ed. (1804), Russland unter Alexander dem Ersten. Eine historische Zeitschrift, Zweiter Band, St. Petersburg und Leipzig: Johann Friedrich Hartknoch.

Tammiksaar, E. (2002), 'Tartu ülikooli zooloogiakateedri eellugu ja rajamine' [A prologue and establishment of the Chair of Zoology at the University of Tartu], 
The Life and Activities of Professor Gottfried Albrecht Germann, the First Natural History Professor at the University of Tartu

Ajalooline ajakiri, no. 1/2 (116/117), pp. 49-58, 312-313.

Tamul, S. (2002), 'Stipendiumid ja teaduskapitalid Tartu ülikoolis aastatel 1802-1918' [Scholarships and donations at the Imperial University of Tartu in 1802-1918], Ajalooline Ajakiri, no. 1/2 (116/117), pp. 177-191, 323-324.

Tamul, S. (2007), Eraalgatuslikest stipendiumidest Tartu Ülikoolis 1802-1918 [Zusammenfassung: Die Private Studienstifungen an der Kaiserlichen Universität Tartu (Dorpat) 1802-1819], Dissertationes Historiae Universitatis Tartuensis 14, Tartu: Tartu Ülikooli kirjastus.

Tarand, A.; Jaagus, J. \& Kallis, A. (2013), Eesti kliima minevikus ja tänapäeval [Estonian climate past and present], Tartu: Tartu Ülikooli kirjastus.

Tering, A. (2008), Eesti-, livi- ja kuramaalased Euroopa ülikoolides 1561-1798 [Estonians, Livonians and Courlanders in European universities in 1561-1798], Tartu: Eesti Ajalooarhiiv.

Tering, A. (2010), 'The dissertations of doctors of medicine active in Estland, Livland and Courland, defended at European universities in the eighteenth century,' Ajalooline Ajakiri, vol. 3/4 (133/134), pp. 367-402.

Tering, A. (2015), 'Contacts in natural sciences between Riga and England in 16601710, Ajalooline Ajakiri, vol. 1/2 (151/152), pp. 39-83.

Tering, A. (2019), Personal report in a telephone conversation with Heldur Sander, 1 April.

Tering, A. \& Beyer, J. (2018), Lexikon der Studenten aus Estland, Livland und Kurland an europäischen Universitäten 1561-1800, Köln, etc.: Böhlau.

The Linnaean Gardens of Uppsala (n.d.), 'Orangeriet - Hybernaculum.' Retrieved from https://www.botan.uu.se/our-gardens/the-linnaeus-garden/explore/garden-tour/ the-orangery---hybernaculum [accessed 17 Oct 2019]

The Plant List (n.d.), [Home page]. Retrieved from http://www.theplantlist.org/ [accessed 18 Oct 2019]

Tohvri, E. (2019), Georges Frédéric Parrot. Tartu Keiserliku Ülikooli esimene rector [Georges Frédéric Parrot: First Rector of the Imperial University of Tartu], Tartu: Tartu Ülikooli Kirjastus.

Trautvetter, E. R. (1880), Florae rossicae fontes, Petropoli: Schumakher.

Vaga, V. (1970), 'E. M. Ulprecht', Kunst, vol. 3, pp. 52-53.

Verzeichnis... (1815), Verzeichnis der Vorlesungen auf der Kaiserlichen Universität zu Dorpat 1802-1815, Dorpat: M. G. Grenzius K. Universitäts-Buchdrucker.

Vilbaste, G. (1939), Póhijooni Eesti floristilisest uurimisest: Ülevaade Vene valitsuse lópuni [An outline of floristic research in Estonia: An overview until the end of the Russian rule], Tallinn: R. Tohver.

Vogg, G. (2008), E-mail to Heldur Sander, 16 September.

Weber, F. Ch. (1721), Das Veränderte Russland, in welchem die ietzige Verfassung des Geistund Weltlichen Regiments..., Frankfurt: Nicolaus Förster. 
Weinmann, J. A. (1810), Botanische Garten der Kaiserl. Universität zu Dorpat im Jahre 1810, Dorpat: M. G. Grenzius.

Willkomm, M. (1873), Der Botanische Garten der Kaiserlichen Universität Dorpat, Dorpat: Mattiesen.

Zigra, J. H. (1805), Verzeichniss derjenigen exotischen Pflanzen, Bäume, Sträucher und samen, welche zu den billigsten Preisen, oder gegen Tauch von Doubletten zu haben sind in der Gartenhandlung von J. H. Zigra zu Riga, Riga: Wilhelm Ferdinand Häcker.

Heldur Sander graduated from the University of Tartu in 1975 with a five-year degree in nature geography and a master's degree in landscape sciences. He has worked as a researcher at the Tallinn Botanical Garden of the Academy of Sciences from 1975-1995, as a contract worker in 1996-1997 there and in forestry science at the Estonian University of Life Sciences in 1998-2010, from where he retired. In 1998, he obtained an MSc degree in geoecology (landscape ecology) from the Tallinn University. His current research interests are in the disciplines of dendrology, urban forestry and history of science. He has studied urban and rural parks and botanical gardens, interlinking the above fields of research. 